\title{
A review on common vegetables and legumes as promising plant-based natural coagulants in water clarification
}

\author{
S. Y. Choy • K. M. N. Prasad • T. Y. Wu • \\ R. N. Ramanan
}

Received: 28 March 2013/Revised: 13 October 2013/Accepted: 19 November 2013/Published online: 18 December 2013

(C) Islamic Azad University (IAU) 2013

\begin{abstract}
Coagulation and flocculation provide a rather straightforward method towards water clarification. However, ongoing debates over worrying health issues linked to chemical coagulants have paved the way to develop plantbased natural coagulants. Natural coagulants are not only water clarifying agents, but they also have antimicrobial and heavy metal removal properties in some instances. These are highly attractive in the transformation of raw surface water into potable drinking water. A total of 14 plant-based natural coagulants categorized as common vegetables and legumes are identified and presented collectively in this comprehensive review. The two main coagulation mechanisms leading to the observed coagulation activities are postulated to be charge neutralization and bridging. Turbidity removal efficiencies were proven to be greatly affected by $\mathrm{pH}$ variations and the dosage of natural coagulants used. The existing research gaps are acknowledged in this work to provide a platform towards the necessity of further research in the water treatment processes.
\end{abstract}

Keywords Coagulation - Flocculation - Protein · Turbidity removal $\cdot$ Antimicrobial properties · Coagulation mechanisms

\section{Introduction}

Approximately $75 \%$ of the universe is covered with water. Yet, some parts of the world have only limited access to

S. Y. Choy · K. M. N. Prasad · T. Y. Wu · R. N. Ramanan ( $ه)$ Chemical Engineering Discipline, School of Engineering,

Monash University, Jalan Lagoon Selatan,

46150 Bandar Sunway, Selangor, Malaysia

e-mail: ramanan@monash.edu this precious commodity. This irony has surfaced since the ancient times and along with mankind's progressive hunger for development; the conditions worsen especially in developing countries and rural areas. According to the statistics at UNICEF/WHO (2009), fatality cases exceeding 1.5 million are reported yearly as a result of the consumption of insanitary water leading to diarrhoea. Among which, $90 \%$ of the cases involve children below the age of five, and in today's world, a child dies from a water-related disease every $21 \mathrm{~s}$. These shocking revelations demand serious attention from all parties globally on the importance of research on water management and sanitation (Gholikandi et al. 2012; Chang et al. 2012; Chen et al. 2012; Chu et al. 2012; Lu and Huang 2012; Luo and Farrell 2013; Nagar et al. 2013; Odiyo et al. 2012; Wang and Wang 2012).

Both the surface water and groundwater provide a continuous mean of water supply to be treated into drinking water (Percival et al. 2000). These water sources could be contaminated with pathogenic microorganisms, dissolved and suspended solids, colour- and odour-causing particles rendering the water to be unsafe for direct human consumption. The presence of such impurities diminishes the quality of the water, and they must be removed effectively. Adequate water sanitation which typically comprises the coagulation and flocculation, sedimentation, filtration and disinfection processes (Ndabigengesere and Subba Narasiah 1998a) is the key to minimizing the health-threatening potentials from the related water-borne diseases.

\section{Coagulation and flocculation}

Turbid water that is murky or cloudy in appearance caused by impurities imparts an unpleasant taste to the water and thus has become the impetus behind the need for water 
treatment. Such colloidal particles are generally too fine to settle by gravity and are usually negatively charged (Kim et al. 2001; Sincero and Sincero 2002). As they are surrounded by repulsive ion charges (Fig. 1), the clumping of the individual particles is hindered. Consequently, they would form a stable suspension and could not be removed without the introduction of a coagulant. With the addition of coagulants (Step 1, Fig. 1), the repulsive ion charges would be neutralized (Step 2, Fig. 1) and particle aggregations would occur. Coagulation is typically the first step in the water treatment process. The significance of the coagulation process lies in its ability to form larger destabilized particles known as microflocs which in turn helps to remove turbidity in the water source. Apart from turbidity, pathogens and other finely dispersed colloids would also be removed to improve the water quality and subsequently leading to better human health. The chronology in the development of coagulation theory and principle has been outlined in detailed elsewhere (Jiang 2001).

Following coagulation, flocculation takes place as the adjunct to the enhancement of the microflocs formation (Bratby 2006) as indicated by steps three to five in Fig. 1. Unlike the former which occurs in $<10 \mathrm{~s}$, flocculation takes a longer period of approximately 20-45 min which is common in water treatment plants (Crittenden et al. 2005). Flocculation can be further classified into two stages: the first being perikinetic flocculation and the second being orthokinetic flocculation (Bratby 2006; Crittenden et al. 2005). Throughout flocculation, the size of the flocs will continue to grow until they reach the steady-state floc size distribution.

\section{Natural coagulants}

The idea of utilizing natural coagulants for the clarification of turbid water is in practice since the ancient times, even way before the advent of chemical coagulants (Ndabigengesere and Subba Narasiah 1998a; Ndabigengesere et al. 1995). Ancient civilizations in India, China and Africa are believed to have used plant derivatives as natural coagulants in their water sources since 2000 years ago (Asrafuzzaman et al. 2011). This is also evident from the Sanskrit writings in India dating back to 400 AD (Dorea 2006; Bratby 2006), the Old Testament and Roman records dating back to $77 \mathrm{AD}$ (Dorea 2006).

Naturally derived coagulants include both the plant- and animal-based resources. Some of the more commonly used animal-based coagulants include isinglass from the shredded fish bladders (Biggs 2007) and chitosan from the shells of crustaceans (Bratby 2006). However, the available sources of plant-based coagulants are much higher than animal-based coagulants, thus suggesting that plant-based coagulants could be potential alternatives to chemical coagulants and have since gained gradual importance over the years.

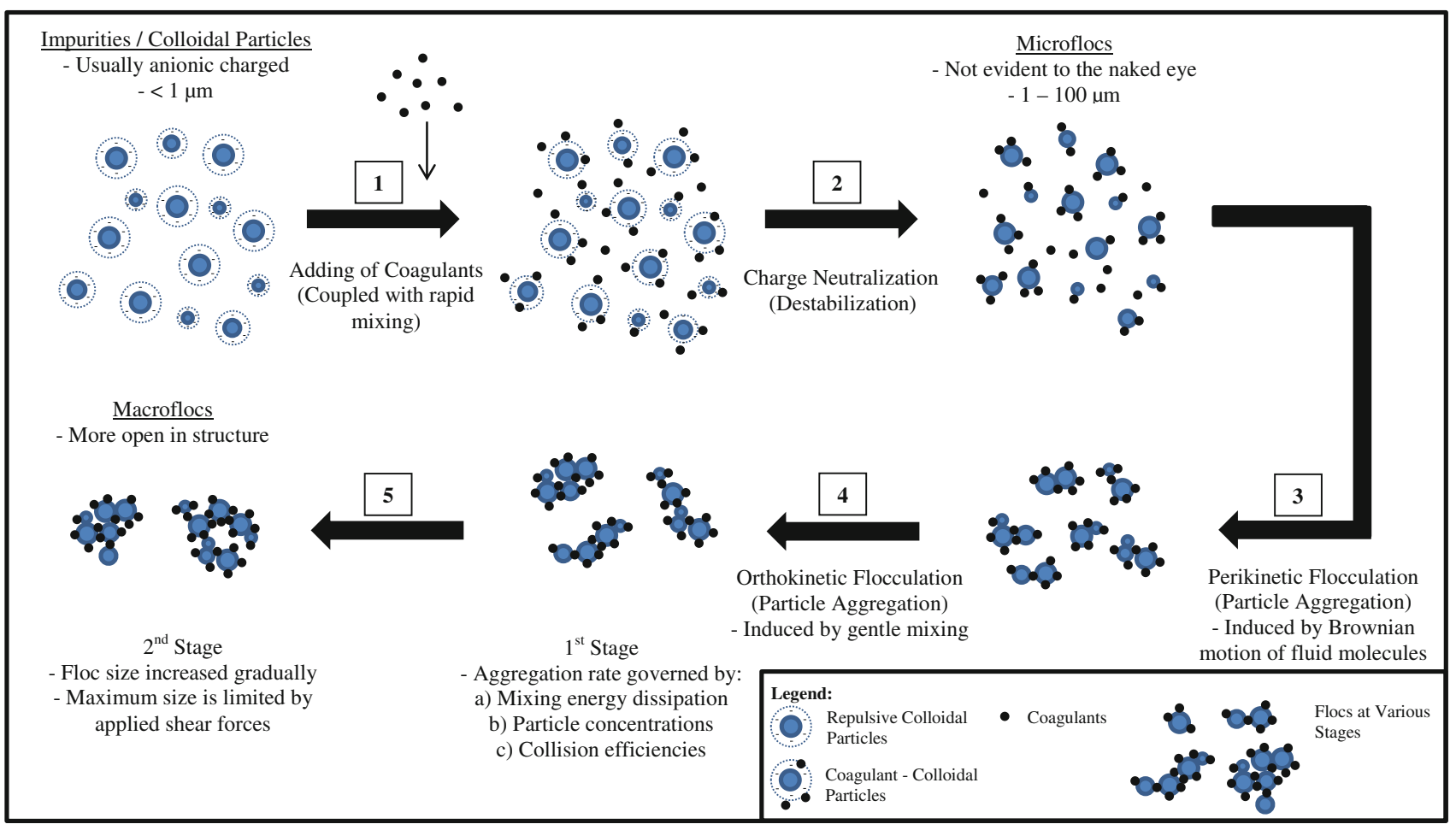

Fig. 1 Coagulation via charge neutralization and flocculation mechanism of the colloidal particles present in water 
Recently, four main plant coagulants namely Nirmali seeds, Moringa oleifera, tannins and cactus that are more commonly known to the water and wastewater industries have been discussed in review papers (Yin 2010; Vijayaraghavan et al. 2011). Another review paper from Yongabi (2010) focused on the indigenous plant coagulants used by the rural Africans for water purification. An extensive review summarizing all the studied natural coagulants along with their additional benefits in the treated water is still lacking. Following this observation, the main motivation of this review paper is driven to compile the potential natural coagulants used and to identify the research gaps from the existing studies conducted. This work also aims to elucidate the coagulation mechanisms responsible for the observed turbidity removals when plantbased natural coagulants mainly vegetables and legumes were utilized in treating turbid waters.

\section{Natural coagulants classified as common vegetables and legumes}

The list of vegetables and legumes studied for their potential as natural coagulants have been summarized in Table 1 with brief accounts to their backgrounds, family classifications and common usages. Majority of the plant coagulants included in this review are legumes under the Fabaceae family which forms an economically important family of flowering plants.

The dimensions of the plant extracts will be handy for the packing process in terms of transportation and storage purposes when handled in bulk quantities. Also, largersized seeds are often favourable as more active coagulants are present relative to the increased seed size. The densities are important to gauge if the plant extracts are to be submerged entirely when added into the water samples for coagulation. The chemical compounds present in these plant coagulants such as protein and carbohydrates could have been responsible for their coagulation activities in water clarification. As such, it might be useful to link these values to the performance of the plant coagulants towards better understanding on their associated coagulation activities. Table 2 provides such information for comparisons among the various plant coagulants.

Table 3 summarizes the studies conducted in treating low to highly turbid water samples using the plant-based natural coagulants and the optimized parameters in achieving the highest turbidity removal.

\section{Coccinia indica/Coccinia grandis}

This herbaceous vine bearing small fruits (Table 1) is commonly referred to as ivy gourd and is a popular vegetable used for culinary purposes. The fruits which are rich in carbohydrates (Table 2) have been used in traditional medicine to cure diabetes, fever and leprosy (Lim 2012). Patale and Parikh (2010), Patale and Pandya (2012) used the mucilaginous extract obtained from this fruit for turbidity removal in synthetic water. Its mucilaginous extract was found to be effective in removing turbidity up to $94 \%$ only in waters with turbidities of 100 NTU (Table 3). The natural anionic polysaccharide present in the mucilage is capable of promoting the formation of particle aggregates which could help in lowering turbidity.

However, the results reported were based on synthetic raw water. The usage of raw surface water would be ideal since it contains diverse types of nutrients, microorganisms as well as colloidal particles. The fruit extract was also reported to be rich in phenolic compounds and has been proven to exhibit antibacterial properties (Shaheen et al. 2009). One of the pathogenic bacteria Salmonella parathyphi could be present in the raw surface water due to the leaching of sewage effluents and can cause waterborne diseases. Thus, further study on this aspect is required when Coccinia indica is used as a natural coagulant.

\section{Hibiscus esculentus/Abelmoschus esculentus}

Hibiscus esculentus commonly referred to as lady's finger is widely consumed as a vegetable which is rich in protein and fibre. Its scientific name 'esculentus' literally means edible and good to eat (Small 2011). The slimy mucilage obtained from the seed pods is used as effective natural coagulant in treating synthetic water and effluent (Anastasakis et al. 2009; Al-Samawi and Shokralla 1996; Agarwal et al. 2001, 2003). A wide range of initial turbidities has been tested up to 3000 NTU (Al-Samawi and Shokralla 1996) in synthetic water, which is crucial to provide an overview of the coagulation performance as high turbidities in surface water are possible especially after a heavy downpour or landslides. Initial turbidities up to $500 \mathrm{NTU}$ are common in other studies conducted using natural coagulants. The performance of alum in turbid water of $100 \mathrm{NTU}$ was enhanced with the addition of this seed extract, leading to higher turbidity removal up to $97.1 \%$. As a result, the usage of alum was minimized by $50 \%$ (Al-Samawi and Shokralla 1996) and is economical especially for industrial applications.

The usage of seed pod extracts as a coagulant under optimized conditions removed more than $80 \%$ of suspended solids from the effluents of sewage (Agarwal et al. 2001) and tannery (Agarwal et al. 2003). The X-ray diffraction analysis of the solid particles collected with and without the addition of the coagulant has shown differences in the values of $2 \theta$ angles and the d-spacing which corresponded to their interatomic spacing. It was then postulated 


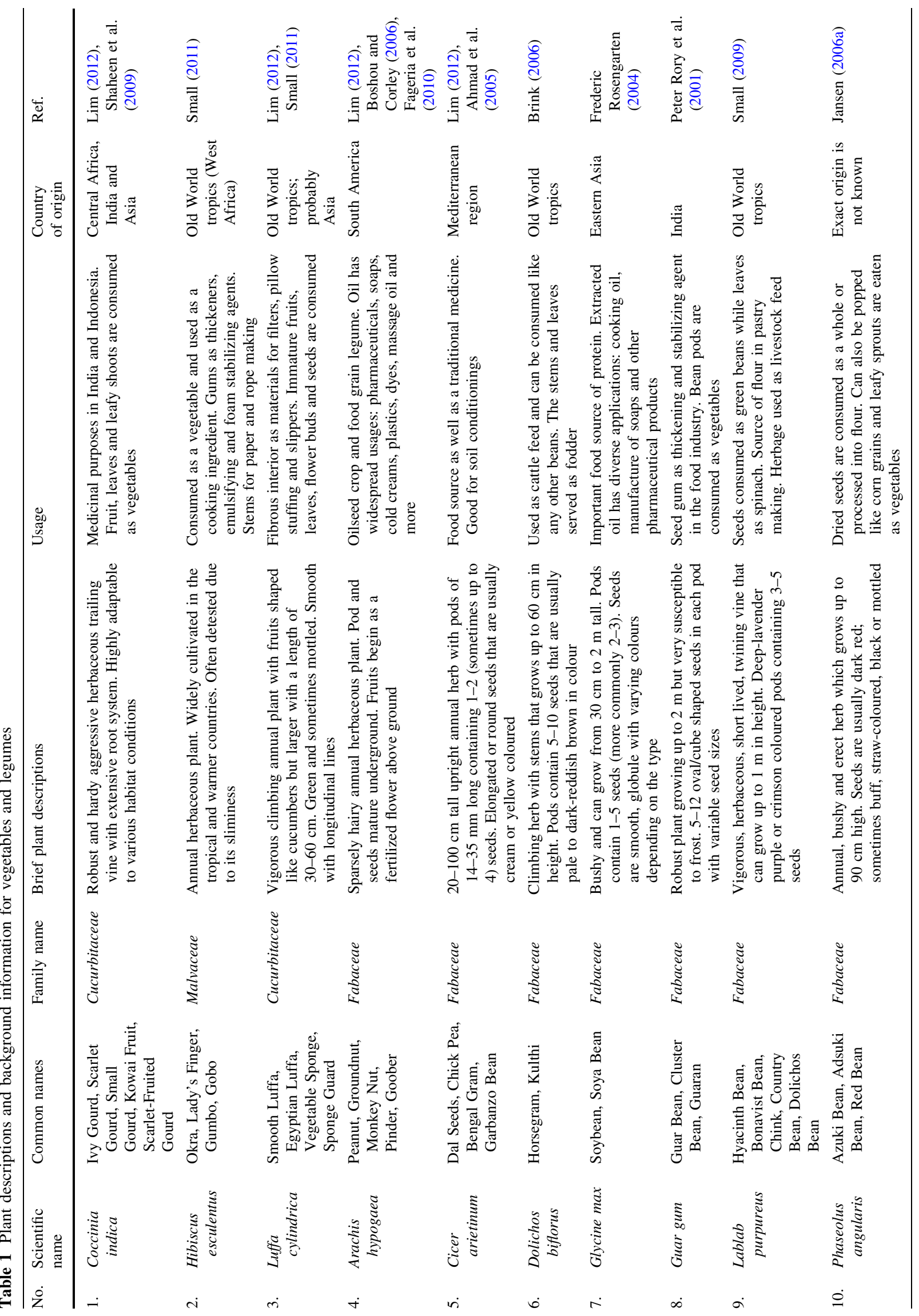




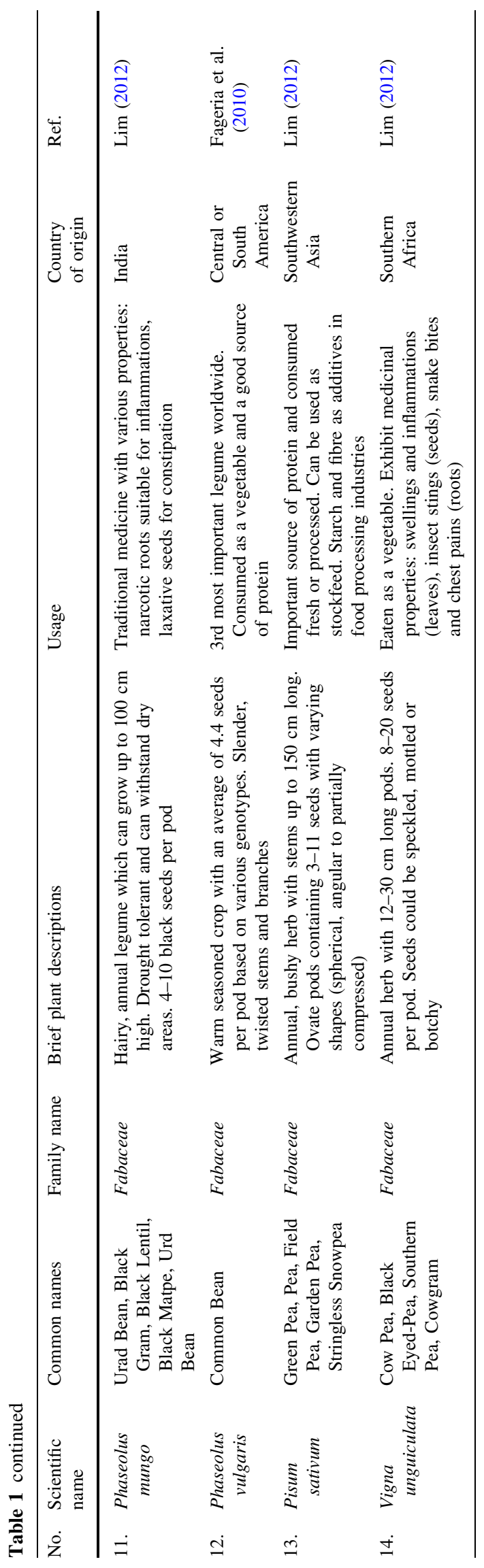

that the primary bonding such as chelation between crystalline matter of the waste and the coagulant might have contributed to the agglomeration of the colloidal particles (Agarwal et al. 2001, 2003). The mucilage of H. esculentus consisted of both polysaccharide and protein fractions which have been found to exhibit strong interactions with one another (El-Mahdy and El-Sebaiy 1984). These fractions have molecular weights (MWs) of $>100 \mathrm{kDa}$ (ElMahdy and El-Sebaiy 1984). On the other hand, commonly used anionic and non-ionic synthetic polymers have much higher MWs exceeding 1,000 kDa (Bolto and Gregory 2007). Thus, it is not surprising that the performance of natural polymers is somewhat less superior as opposed to those of chemical nature.

Turbidity removal in synthetic wastewater and biologically treated effluent was compared between $H$. esculentus and Malva sylvestris. The former exhibited a higher turbidity removal efficiency in the effluent sample at a much lower dosage (Anastasakis et al. 2009). However, the dissolved organic carbon content was increased in the treated effluent due to the addition of these plant coagulants (Table 3). The mucilage compositions of these plants might have influenced their resulting coagulation activity, and this warrants further study. The antimicrobial properties of this plant has shown potential against the inhibition to some of the tested bacteria such as Escherichia coli and Staphylococcus aereus which are commonly present in surface water (De Carvalho et al. 2011). Hence, it would be of great interest to study both its coagulation activity as well as the bacteria inhibition in the treatment of raw surface water for drinking purposes.

\section{Luffa cylindrica/Luffa aegyptiaca}

Due to its highly fibrous and sponge-like interiors, Luffa cylindrica is also known as sponge guard. This climbing plant is usually consumed as a vegetable when unripe as it lacks in the network of fibres (Small 2011). When the plant extract was added to raw surface water samples, turbidity reduction close to $85 \%$ has been reported (Sowmeyan et al. 2011). As the exact part of the plant used was not specified, it can be postulated that either the seeds or the whole fruit exhibited such coagulative properties due to their similarities in terms of the high carbohydrate and protein contents (Table 2).

While most of the plant extracts undergo aqueous washing as part of the pretreatment process, Sowmeyan et al. (2011) introduced the formaldehyde or acid-alkaline wash. These solvents have been reported to be capable of removing organic matters and are commonly used in the ion exchange technology (Snoeyink and Scott Summers 1999). Hence, it can be assumed that some degree of organic matters from the plant extract has been removed 


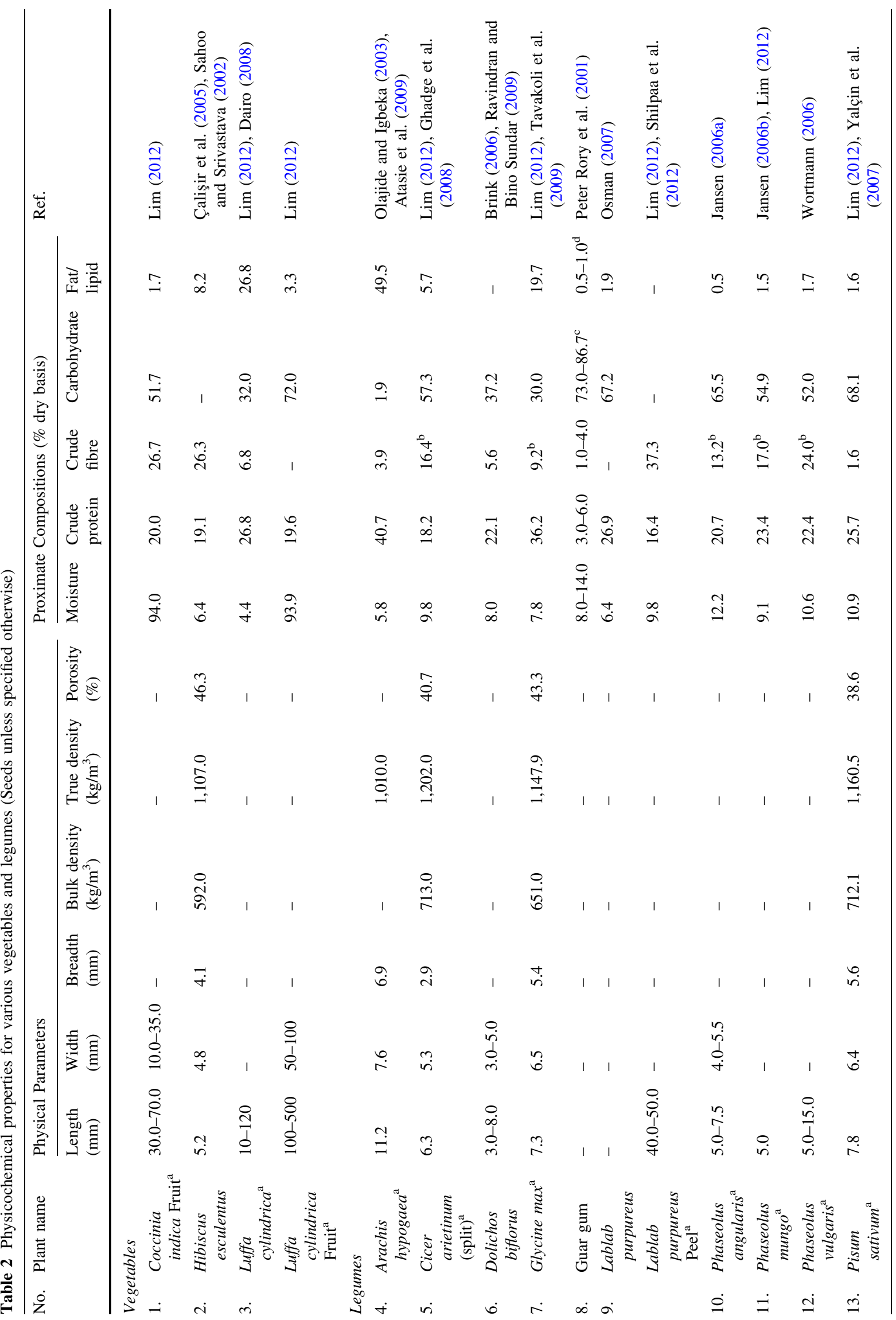

4 Springer 


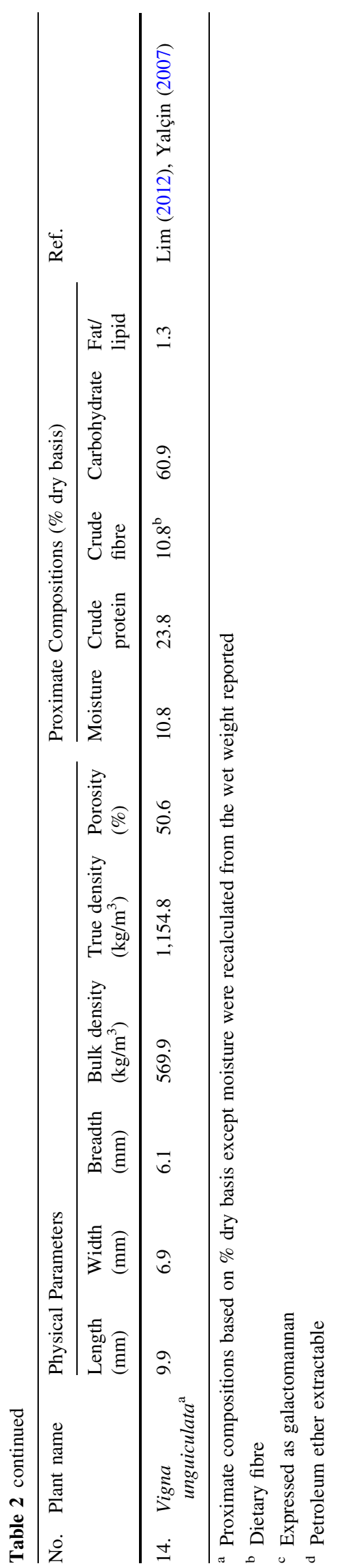

prior to the addition to the sample to reduce the leaching of organic matters. This is to be justified by measuring both the content of organic loadings in the sample before and after the addition of the plant extracts.

Antimicrobial properties in the aqueous extract of the powdered fruit as well as the seed extracts of $L$. cylindrica were observed against total and faecal coliform bacteria when added to raw surface water (Shaheed et al. 2009). The seed extracts which contained more antimicrobial constituents such as saponins and steroidal rings exhibited greater potency. The phytochemical profile as well as the antibacterial properties of the seeds and leaves has also been studied elsewhere (Oyetayo et al. 2007). However, the disinfection achieved for drinking water relying solely on this coagulant would not be sufficient (Shaheed et al. 2009). This plant extract has also been reported to remove heavy metals, fluoride and chlorides. Even so, it is more superior compared to the other studied coagulants in terms of removal of total dissolved solids (TDS) up to $60 \%$ (Sowmeyan et al. 2011).

\section{Arachis hypogaea}

Arachis hypogaea or peanut is a good source of protein and is best known for its high oil content. The seeds are valuable in traditional medicine due to its anti-inflammatory properties, while the extracted oil is usually the basis of ointments (Lim 2012). The lipidic fraction in A. hypogaea contributes close to half of its dry weight (Table 2). Since lipid does not contribute to its coagulation activity, the relative concentration of the active agents is largely reduced, resulting in poorer turbidity removal in raw surface water (Table 3). Although the effect of delipidation is lacking, similar outcomes can be expected from the studies conducted on the seeds of Moringa stenopetala (Mataka et al. 2006). The delipidated cakes outperformed the crude seed extract in terms of heavy metal removal and the required coagulant dosage. Thus, it is strongly believed that the coagulation activity in A. hypogaea can be enhanced with the removal of this fraction.

Differences in the efficiency of turbidity removals between two studies were observed (Mbogo 2008; Subramanium et al. 2011). The characteristics of the raw surface water used in both the coagulation studies might have contributed to this contrast. The presence of high organic matters in water with greater surface charge has been found to dominate the coagulation process (Kim et al. 2001). Hence, it affected the neutralization of these colloidal particles and resulted in increased residual turbidity. The presence of multi-charged ions such as bivalent ions of magnesium and calcium could have aided the coagulation process. Studies have proven that the addition of these ions can help to reduce the residual turbidity (Tripathi et al. 


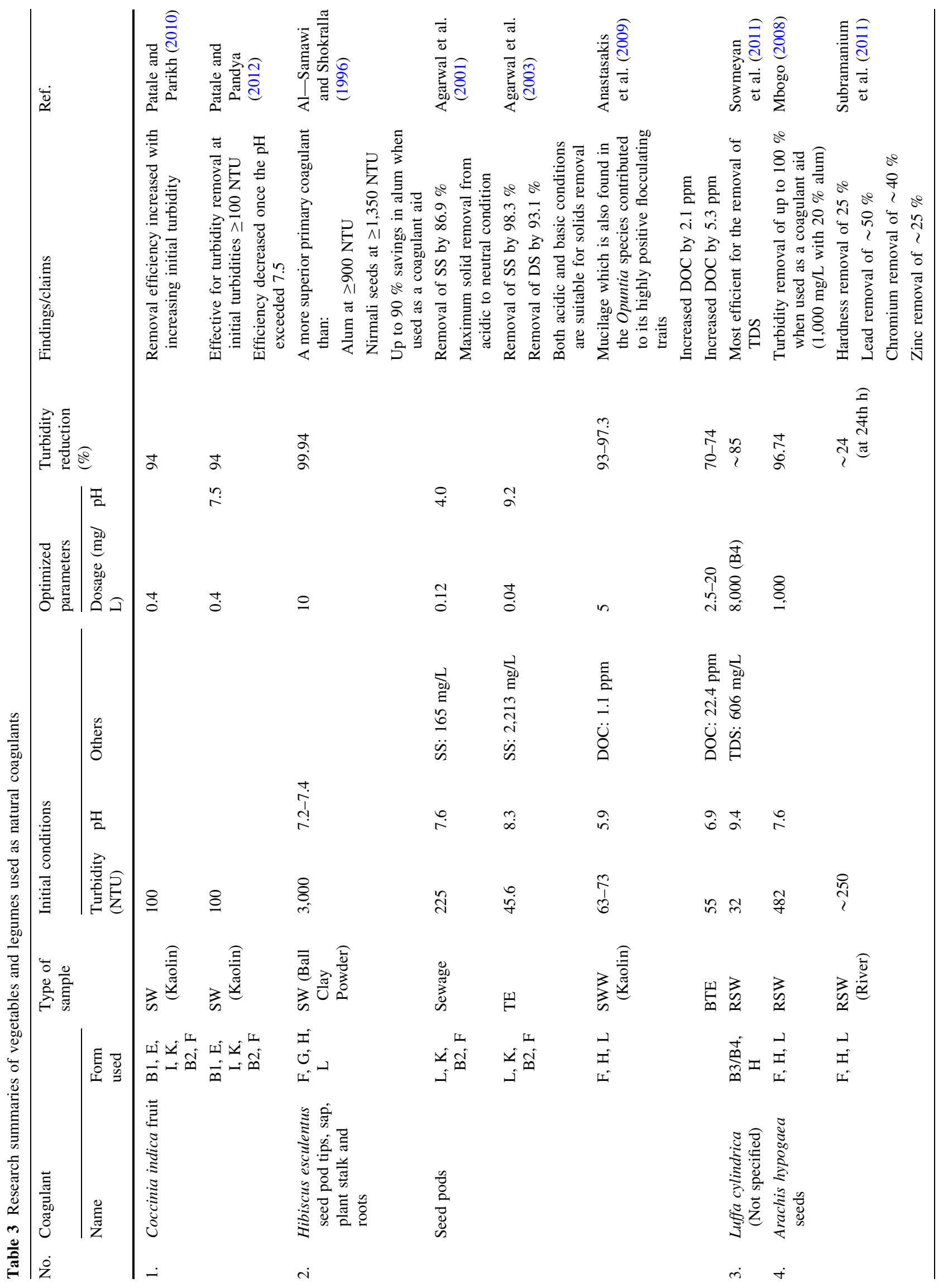




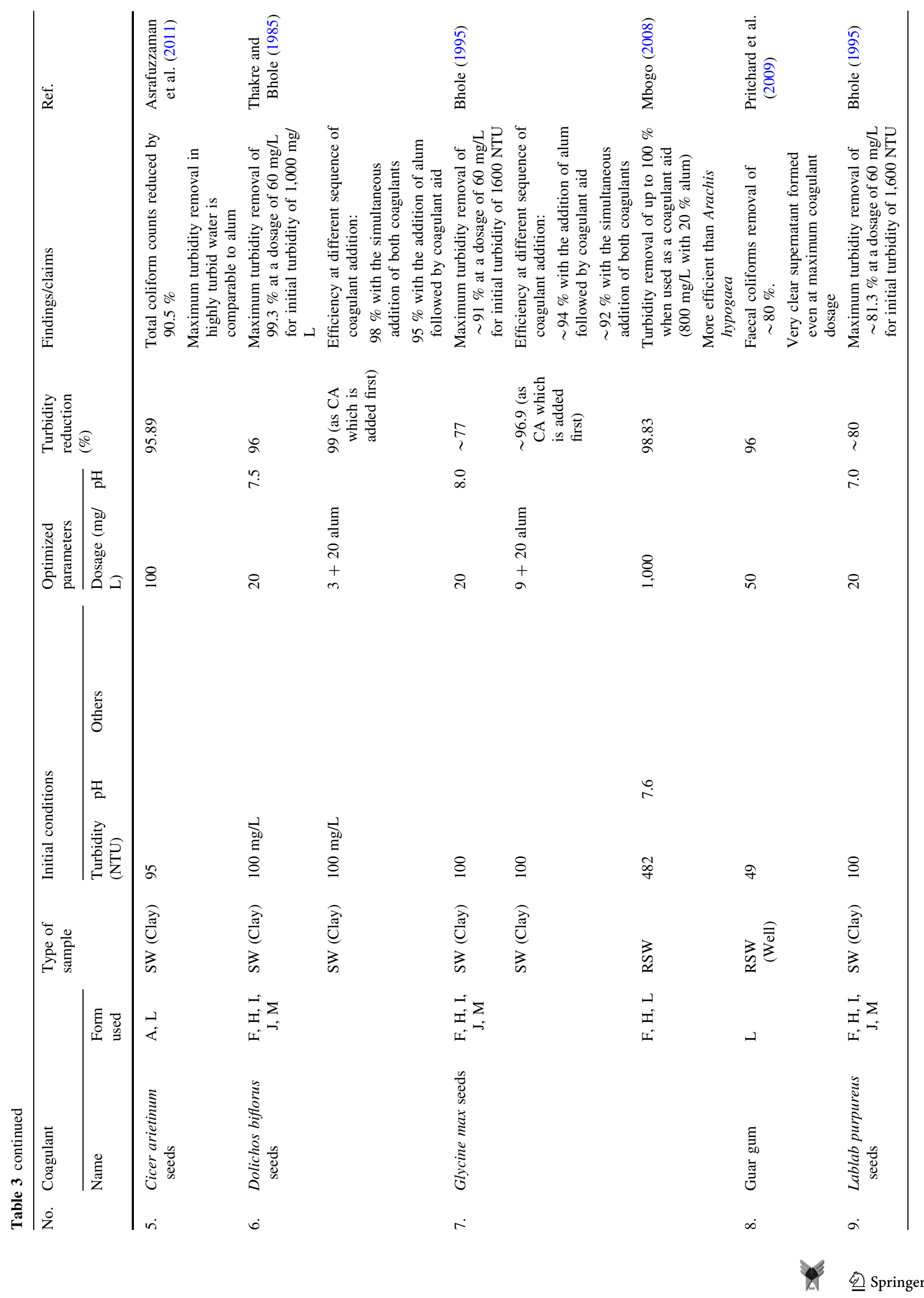




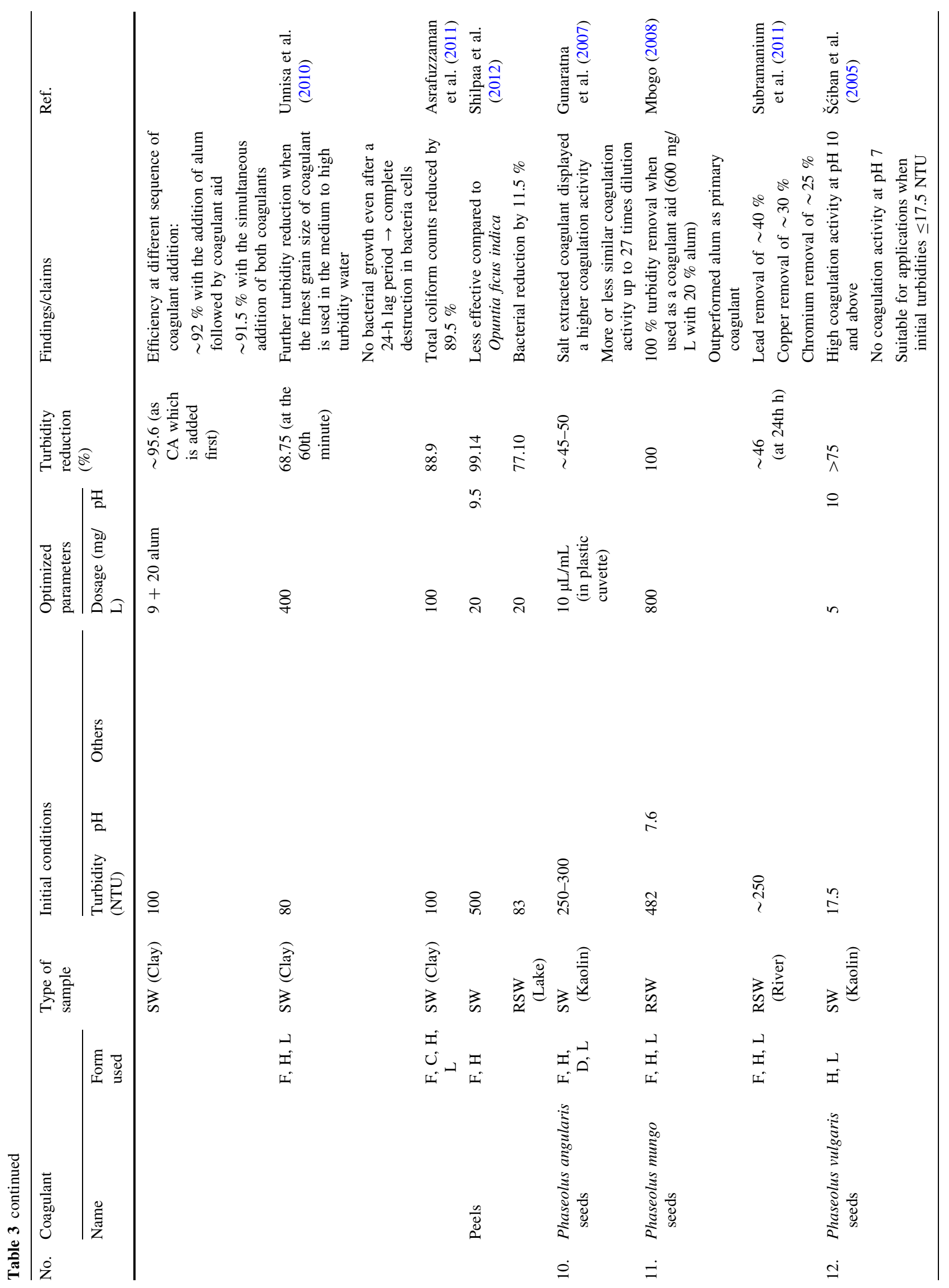




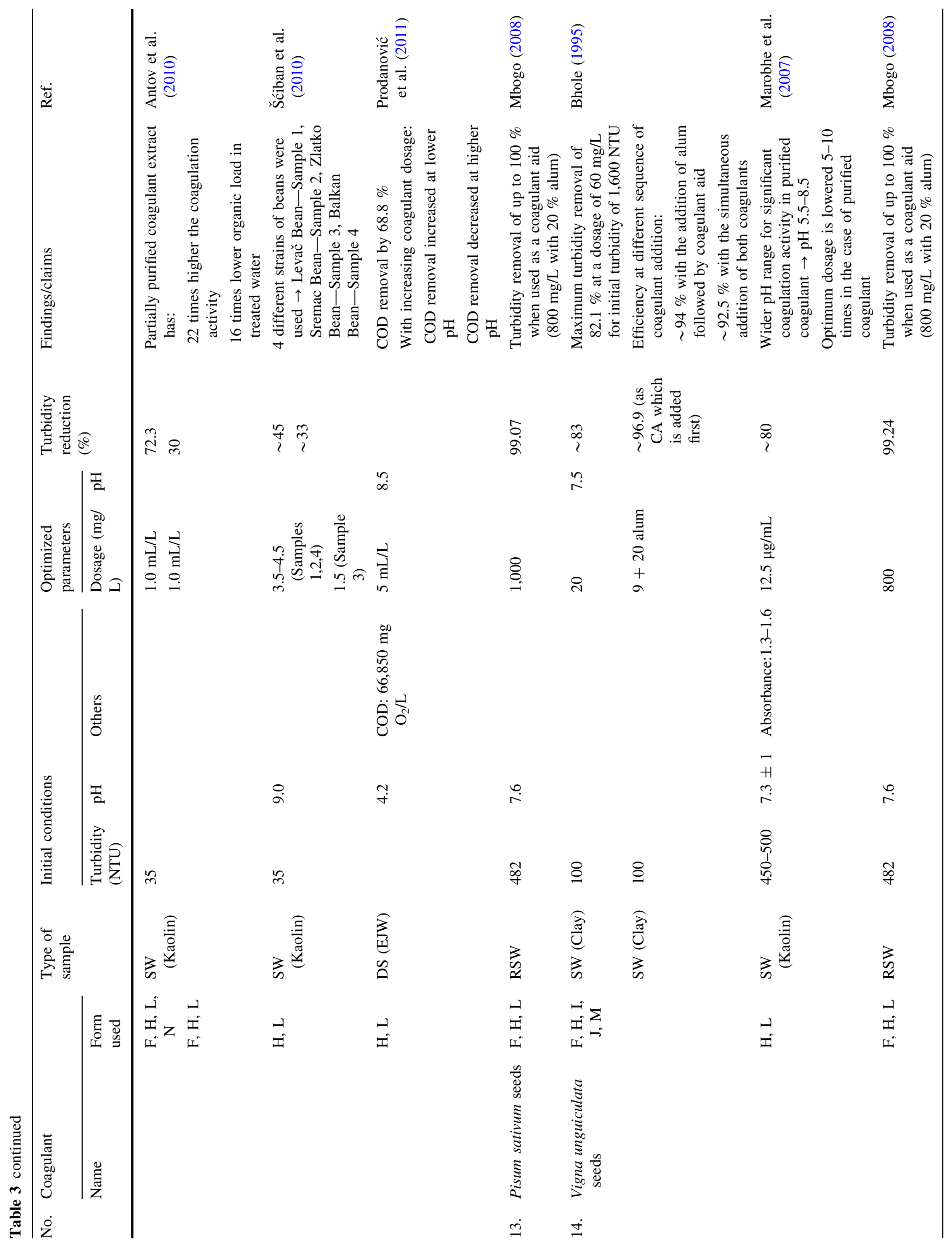




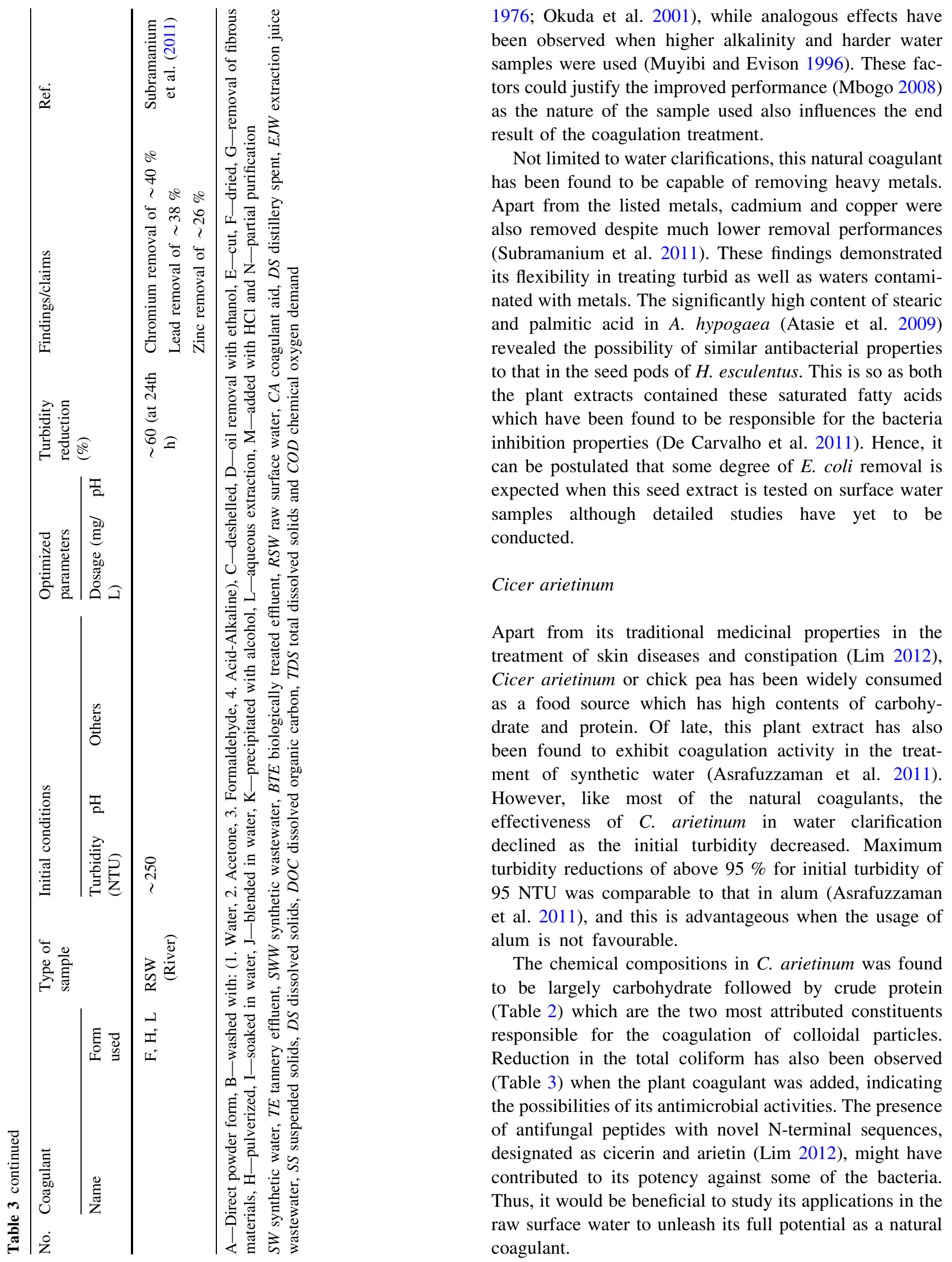




\section{Dolichos biflorus}

Also known as horsegram, this climbing plant is usually made into silage. With its high nutritional content, especially protein and carbohydrates, the Dolichos biflorus seeds are also eaten as beans (Table 1). Besides its conventional usages, the seeds have been added as natural coagulants to treat synthetic water with initial turbidities ranging from 25 to $1,600 \mathrm{mg} / \mathrm{L}$. Turbidity removals above $95 \%$ in synthetic water under optimized conditions have been reported when used alone and in conjunctive usage with alum (Thakre and Bhole 1985), indicating its potential as an effective primary and coagulant aid. The plant extract worked best at $\mathrm{pH}$ values near neutral of 7.5 which is ideal considering the normal $\mathrm{pH}$ of surface water to be within 7-8 (Bhole 1995).

The order at which the coagulants were added has altered the treatment results (Table 3 ). If alum was first added, the alkalinity and $\mathrm{pH}$ levels in the sample would be reduced due to its working properties. When the extract of $D$. biflorus seeds was added next, its performance in promoting particle agglomerations declined as it has been reported to work well at $\mathrm{pH}$ near neutral. Thus, the resultant turbidity removal was lowered compared to the addition of the seed extracts followed by alum (Thakre and Bhole 1985). Despite its much lower protein content (Table 2), its overall performance as a natural coagulant is generally more efficient compared to Vigna unguiculata, the seeds of Lablab purpureus and Glycine max in the order of decreasing turbidity removals. The synergistic effects among the chemical constituents as well as the characteristics of the active coagulants present in each of the individual seeds might have contributed to this observation.

\section{Glycine max}

Widely known as soybean, the G. $\max$ plant is the most important source of vegetable oil, accounting for more than $50 \%$ of the world's oilseeds (Frederic Rosengarten 2004). Its genus name 'Glycine' has been derived with reference to the Greek word 'glykys' which means sweet, thus indicating the sweetness of fruits from some of the species (Small 2009). Like most legumes, the seed extracts were reported to exhibit water clarification properties when tested in synthetic water (Bhole 1995) and highly turbid raw surface water (Mbogo 2008) as the primary coagulant and coagulant aid to alum. This plant coagulant is more superior in the treatment of surface water beyond $450 \mathrm{NTU}$ (Mbogo 2008), suggesting its improved performance as the initial turbidity increases. Turbidity removals of $>96 \%$ (Table 3) have been observed when the plant extract was used as a coagulant aid to alum. This indicated an overall improvement compared to the sole addition of alum in water treatment.

The soybeans contained relatively large fraction of lipid and is the second highest legume trailing behind A. hypogaea (Table 2). This fraction does not contribute to coagulation activities, and delipidation of the seeds will be useful if enhancement in its turbidity removal is required as the relative concentration of the active agents has been increased. In addition to turbidity removal, delipidated or deoiled soybeans have also been recently studied as lowcost bio-adsorbents in the treatment of various dye-contaminated water (Mittal et al. 2008, 2009a, b, 2010a, b, c; Gupta et al. 2009). Palmitic and stearic acids which contributed to the bactericidal activities in H. esculentus (De Carvalho et al. 2011) are also present in G. $\max$ (Lim 2012). Hence, this plant extract could also exhibit potency against some of the bacteria present in raw surface water.

\section{Guar gum from Cyamopsis tetragonoloba}

The endosperm splits of seeds from the sun-loving plant of Cyamopsis tetragonoloba or commonly known as cluster beans produce the guar gum flour (Peter Rory et al. 2001). This food gum is 'Generally Recognized as Safe' by the US Drug and Food Administration (Melnick et al. 1983), and little evidence was linked to its adverse human health impacts (Peter Rory et al. 2001). Thus, this plant extract is safe for human consumption when used as a natural coagulant. The treatment of water samples with initial turbidities below 50 NTU obtained from five shallow wells has been studied with the addition of guar gum (Pritchard et al. 2009). Surprisingly, a $100 \%$ turbidity removal was reported for an initial turbidity of 1 NTU despite the removal trend to be somewhat affected by the degree of initial turbidity. Even so, its overall performance when treating higher-initial turbidity waters up to 49 NTU fared better than Jatropha curcas but less superior compared to M. oleifera (Pritchard et al. 2009).

Guar gum is extremely low in protein content if compared to other legume sources which acted as natural coagulants (Table 2), suggesting that protein might not be the dominating active agents responsible for its coagulative activities. In fact, guar gum which is a neutral polysaccharide (Bratby 2006) is highly rich in carbohydrate in the form of galactomannan. Guar gum also has high molecular weights of 50,000-8,000,000 (Mirhosseini and Amid 2012). This large polymeric structure is also more polydisperse compared to another natural coagulant, the locust bean gum (Lawrence 2003). As such, it can be postulated that guar gum is more superior in removing turbidity considering the much easier dispersion and at least 2.5 times greater in terms of molecular weight (Mirhosseini and Amid 2012). 
The faecal coliform contents in the treated water also showed significant reductions. However, this does not comply with the requirements of achieving zero colonyforming units (cfu)/100 mL as stipulated by WHO, and subsequent disinfections are necessary to ensure adequate water sanitation (Pritchard et al. 2009). Bacteria might have been removed along with the colloidal particles, and the antimicrobial properties of guar gum demands additional research to identify the possible chemical constituents leading to its bacteria inhibitions.

\section{Lablab purpureus}

The L. purpureus plant often bears lavender-purplish flowers, thus contributing to its genus name 'purpureus' (Small 2009). This robust growing creeper commonly known as hyacinth bean (Table 1) has been studied as a primary coagulant as well as an aid to alum (Bhole 1995). Turbidity removal in synthetic water was increased by $15 \%$ when added as a coagulant aid (Table 3). At 1,600 NTU, further turbidity removal of up to $82 \%$ was reported (Bhole 1995). Its effectiveness in treating turbid water was greatly enhanced when used as a coagulant aid. This could provide an alternative means in bid to reduce the dependency on chemical coagulants. In general, the peels of $L$. purpureus (Shilpaa et al. 2012) can be postulated to be more efficient as a relatively small dosage is capable of achieving higher turbidity removal.

The turbidity removals in two relatively similar initial conditions of the studied synthetic water (Unnisa et al. 2010; Asrafuzzaman et al. 2011) varied by at least $20 \%$ (Table 3). Both the sedimentation times were approximately $60 \mathrm{~min}$, but the coagulant dosage required was four times larger when shelled seeds were used (Unnisa et al. 2010). This clearly implied that the shell removal of $L$. purpureus seeds is beneficial as it increases the relative concentrations of the active coagulant compounds. Thus, higher turbidity removal can be achieved while reducing the coagulant dosage. This is also in close agreement with the usage of deshelled $M$. oleifera seeds as natural coagulants which have shown similar trends (Ndabigengesere and Subba Narasiah 1998a, b). The chloroform and n-hexane extracts of $L$. purpureus have been found to be significantly potent against the range of bacteria tested (Lim 2012). As aqueous extractions of natural coagulants are commonly adopted, its antimicrobial activity in this solvent would be useful particularly for the treatment of drinking water.

\section{Phaseolus angularis}

Phaseolus angularis, widely known as red bean, is high in proteins and carbohydrate (Table 2). The active protein coagulant was found to be of cationic nature with similar properties to that in the seeds of $M$. oleifera (Gunaratna et al. 2007). However, its turbidity removal in synthetic water was outclassed by the latter, which could be due to its 1.7 times lower protein content (Compaoré et al. 2011) despite having larger protein molecular weight. Even though the carbohydrate content is about 7.3 times greater (Compaoré et al. 2011), this fraction which is also responsible for the particle coagulation does not seem to have much influence on the corresponding activity. The limited presence of the branched polysaccharides such as amylopectin which leads to effective coagulation in the roots extract of Maerua subcordata (Mavura et al. 2008) could also be accounted for the decreased coagulation activity. Along with its reduced protein content, it is not surprising that $M$. oleifera is more efficient as the active agents have been identified to be that of protein nature (Ndabigengesere et al. 1995).

The resulting coagulation activity was sustained regardless of the number of dilution factors (Gunaratna et al. 2007). This is economically beneficial as both the diluted and concentrated protein extracts can achieve relatively similar coagulation activities. In fact, the diluted protein extracts showed improved coagulation activity that was lower compared to M. oleifera. Gunaratna et al. (2007) also discovered that the protein coagulant was stable at elevated temperatures beyond $85{ }^{\circ} \mathrm{C}$ with $30 \%$ enhanced activity, but its turbidity removal remained fairly low, which is undesirable for the treatment of drinking water.

The tannin constituent from the seeds of $P$. angularis exhibited antibacterial activities against $E$. coli and other bacteria which are the common causes of waterborne illnesses in surface water (Amarowicz et al. 2008). Polyphenols present in this coloured seeds were proposed as the possible cause leading to bacterial inhibitions (Hori et al. 2006). However, the susceptibility towards polyphenols is dependent on the characteristics of the individual microorganisms. Its conjunctive usage as a natural coagulant for both turbidity and microorganism removal warrants further research to gauge its full potential if it is to be adopted in the existing water treatment technology.

\section{Phaseolus mungo/Vigna mungo}

In India, the Phaseolus mungo plant or black gram is a pulse crop that is largely grown for the production of dhall (Lim 2012). This annual plant is also grown for forage and has widespread applications as a traditional medicine. Recently, its potential as a natural coagulant has been studied in treating highly turbid raw surface water (Mbogo 2008; Subramanium et al. 2011). The seed extracts were capable of removing $100 \%$ turbidity at a reduced dosage by $20 \%$ to outperform alum as a primary coagulant 
(Mbogo 2008). Also, P. mungo was found to be the most efficient natural coagulant compared to $V$. unguiculata, Pisum sativum, G. max and A. hypogaea in the decreasing order of efficiency in water clarification. This could be due to its higher protein content (Table 2 ) with $<2 \%$ of lipid fraction. The cationic nature of its polyelectrolytes as well as protein (Subramanium et al. 2011) is essential for the neutralization of the colloidal particles which promoted the formation of flocs.

The seed extracts of $P$. mungo have additional advantage when used in water treatment. Heavy metals such as lead, copper and chromium were removed by more than $25 \%$ along with smaller removal fractions of hardness, zinc as well as cadmium (Subramanium et al. 2011). This is beneficial when such metals are present in raw surface water and must be removed to meet the drinking water quality. However, it lacks superiority in comparison with the extracts of $M$. oleifera (Subramanium et al. 2011). Other heavy metal removal techniques such as the use of carbon nanotubes as adsorbents could be employed to enhance their removal in contaminated water (Gupta et al. 2011a, b).

\section{Phaseolus vulgaris}

Also known as common bean, this plant is the most widely distributed and consumed seed legume in the species of Phaseolus globally (Fageria et al. 2010). Its expanded usages is not only limited to providing traditional remedies against diabetes mellitus (Lim 2012), but also as a potential natural coagulant in removing turbidity. However, its turbidity removals in treating lowly turbid synthetic water of $<40$ NTU (Antov et al. 2010; Śćiban et al. 2010) have been found to be below $50 \%$ (Table 3 ). This is so as the findings by Ściban et al. (2005) showed that the seed extracts of Phaseolus vulgaris performed well at $\mathrm{pH}$ values beyond 10 and has good coagulation activities at turbidities below 18 NTU. Since the water conditions were not adjusted to the optimized treatment conditions, the performance of the seed extracts have yet to reach the pinnacle indicating the importance of $\mathrm{pH}$ control. This extract is useful when treating such lowly turbid water as turbidity removals $>75 \%$ (Šćiban et al. 2005) have been reported.

Partial purification of these protein coagulants have also been studied and compared against the coagulation activity of the crude proteins (Antov et al. 2010). This additional pretreatment step is highly important to lower the introduction of organic loadings (Ghebremichael 2007) which is a common issue when using natural coagulants and to reduce the dosage of coagulant in achieving similar coagulation activities. The molecular weight of the trimer coagulant protein subunit is approximately $50 \mathrm{kDa}$ which is larger than that in M. oleifera. As the seeds of $P$. vulgaris contained a much smaller fraction of lipid, this eliminates the need for delipidation and is highly beneficial in terms of economic and environmental concerns (Antov et al. 2010).

Two commercial treatment processes, centrifugation and coagulation using plant coagulants, were compared for various distillery wastewaters. The usage of the seed extracts in the extraction juice wastewater sample yielded COD removals up to $69 \%$ under optimized parameters as opposed to centrifugation (Prodanović et al. 2011).

\section{Pisum sativum}

Pisum sativum or pea is rich in carbohydrate and protein, which makes it an important food source that is consumed fresh or as raw material in the canning industry. This bushy plant also served as a traditional relief to various skin problems, and with good gel strength, its starch is used in the production of packaging materials (Lim 2012). Positive results have been reported when the aqueous extract of the seeds were used to clarify highly turbid surface water (Mbogo 2008). At a similar coagulant dosage of $1,000 \mathrm{mg} /$ L, improved performance compared to $G$. max and $A$. hypogaea, both having higher protein contents by at least 1.4 times (Table 2), has been observed (Mbogo 2008). It can then be anticipated that their resulting coagulation activity would also be greater considering the active agents contributing to coagulation are often proteins.

However, the mixture of chemical constituents in the extracts could have synergistic effects towards coagulation and the carbohydrate fraction consisting of starch could also be one of the coagulation agents. Starch, a non-ionic polymer, could have been responsible for its relatively high turbidity removal apart from the protein coagulant. This explains its improved coagulation efficiency whereby the larger fraction of carbohydrate has dominating effect towards particle aggregations. The coagulation activity in the plant extracts such as those from the roots of $M$. subcordata (Mavura et al. 2008) and seeds of Zea mays (Raghuwanshi et al. 2002) has also been attributed to the presence of starch.

Good bacteria inhibition against 56 isolates belonging to 11 different species of Gram-negative bacilli has been reported (Saeed and Tariq 2005). The growth of pathogenic bacteria commonly present in the raw surface water such as E. coli and Salmonella spp. could be effectively retarded as the seeds are rich in phenolic antioxidant (Saeed and Tariq 2005). As the juice of fresh seeds (Saeed and Tariq 2005) was used, differences in the resulting bacteria inhibition may exist when the aqueous extract (Mbogo 2008) is tested on contaminated surface water due to the variations in the working form. However, this study has provided a platform towards the potential for microorganism removal when used as a natural coagulant. 


\section{Vigna unguiculata}

Vigna unguiculata or cow pea has long been recognized as a major food staple, especially in most of the African countries (Lim 2012). Besides its traditional medicinal applications (Table 2), the seed extracts were reported to exhibit coagulation activities when tested on turbid synthetic water (Bhole 1995; Marobhe et al. 2007) and raw surface water (Mbogo 2008; Subramanium et al. 2011). Generally, turbidity removals of $>80 \%$ can be attained with the usage of these seed extracts regardless as a primary or as a coagulant aid (Table 3), but the result presented in one of the studies fell below this minimum percentage (Subramanium et al. 2011). It is likely due to the absence of dosage optimization as the turbidity removal is not maximized. Turbidity removals were enhanced at higher initial turbidities as observed for most of the natural coagulants.

The coagulation activities in the crude and purified protein coagulant from the seeds of $V$. unguiculata have been studied under various conditions (Marobhe et al. 2007). The purified cationic proteins through ion-exchange chromatography have similarities with the protein coagulant in $M$. oleifera. Two or more coagulant proteins were reported to be present in this extract (Marobhe et al. 2007). Purification of the protein coagulant enabled significant dosage reductions in achieving comparable results to that in the crude protein with the potential of removing the associated organic load introduced in the treated water. Both the crude and purified extracts of $V$. unguiculata could retain at least $85 \%$ of the coagulation activities when heated at $40{ }^{\circ} \mathrm{C}$ but became highly sensitive after prolonged heating at much higher temperatures of above $80{ }^{\circ} \mathrm{C}$ (Marobhe et al. 2007). Given the lower temperature of the surface water, coagulation activities would not be affected with the usage of this plant coagulant.

The extracts were also capable of removing $<25 \%$ of hardness, cadmium and copper apart from its water clarification activities (Subramanium et al. 2011). Although its bacteria inhibitions in surface water are still lacking, studies have concluded the presence of various proteins with antifungal and antiviral potency in the seeds of V. unguiculata (Lim 2012), which may lead to some form of water disinfection properties.

\section{Coagulation/destabilization mechanisms}

Coagulation or destabilization of the suspended colloidal particles can be achieved via four mechanisms, namely the double-layer compression, charge neutralization, bridging as well as sweep coagulation (Crittenden et al. 2005). The coagulation mechanisms work based on different principles and one or more mechanisms could be employed for more effective particle destabilizations.

\section{- Double-layer compression}

This coagulation mechanism relied on the addition of an 'indifferent' electrolyte in large quantities. The high ionic solution introduced in an existing system would alter the overall ionic concentration. Thus, the double layer surrounding the colloidal particle would be compressed to a certain extent where the repulsive energy barrier will also be lowered. This phenomenon will encourage the binding of two molecules and subsequently aid in the formation of flocs. However, the effectiveness of this coagulation mechanism is questionable and is usually not preferred. The presence of bivalent ions such as $\mathrm{Ca}^{2+}$ and $\mathrm{Mg}^{2+}$ in water has been attributed to induce some form of coagulation activities via the double-layer compression mechanism (Duan et al. 2009).

\section{- Charge neutralization}

This coagulation mechanism involves the adsorption of an oppositely charged coagulant on the colloidal surface. The colloidal particles are usually negatively charged under normal surface water conditions. Hence, positively charged coagulants will be attracted towards the colloids, subsequently resulting in surface charge neutralizations. The quantification of zeta potential is highly beneficial in predicting the optimum coagulant dosage required to achieve effective coagulation. A near-zero net charge would provide a clear indication of the ideal coagulant dosage sufficient for complete charge neutralizations. As such, the effectiveness of this mechanism is strongly dependent on the coagulant dosage introduced; particle restabilization could easily occur once the optimum dosage is exceeded. The cationic protein fraction from natural coagulants such as the seeds of $M$. oleifera (Ndabigengesere et al. 1995) and J. curcas (Abidin et al. 2011) has previously been reported to work under this coagulation mechanism.

\section{- Adsorption and bridging}

The bridging of particles occurs with the introduction of long-chain polymers or polyelectrolytes as these coagulants are capable of extending into the solution to capture and bind multiple colloids together. The bridging efficiency is further improved when coagulants with larger molecular weights are used due to the extended polymeric chains. Natural polymers such as polysaccharides and proteins could also induce coagulation via bridging. The mucilage of cactus Opuntia ficus indica which is an anionic 
polysaccharide has been proven to result in particle removals via this mechanism (Miller et al. 2008).

\section{- Sweep coagulation}

The formation of coagulant precipitates via the addition of an unusually large coagulant dosage is the backbone leading to sweep coagulation. These particles could act as nucleation sites to facilitate the precipitation formation (Sincero and Sincero 2002). As the precipitate forms, colloidal particles would be enmeshed in the growing precipitate and thus could be successfully removed from the colloidal suspension. Sweep coagulation could result in improved coagulation for greater removal performance in comparison with charge neutralization (Duan and Gregory 2003). As a far greater coagulant dosage than that for the latter is required, the larger amount of sludge generated at the end of the coagulation process may not be favourable. Unlike chemical coagulants such as alum, plant-based natural coagulants may not employ sweep coagulation as the turbidity reductions observed generally declined at elevated coagulant dosages beyond the optimum values (Agarwal et al. 2001; Al—Samawi and Shokralla 1996).

Table 4 provides a concise summary of the key features and characteristics of each coagulation mechanisms. The floc characteristics have been compiled from the results obtained using chemical coagulants specifically alum. However, the same can be anticipated for plant-based natural coagulants due to the relevance of the appropriate coagulation mechanisms. Based on the nature and type of natural coagulants, the main coagulation mechanisms responsible for the observed turbidity removals (Table 3 ) could most likely be charge neutralizations and bridging.

It is also important to note that the performances of these two coagulation mechanisms are strongly affected by $\mathrm{pH}$ as well as the coagulant dosage. Hence, subsequent optimization studies would be worthwhile to maximize the full potential of plant-based natural coagulants in achieving the highest turbidity reductions. The significance of these critical parameters will be discussed further in the following subsections.

\section{Influence of $\mathrm{pH}$ on turbidity reductions}

The isoelectronic point $(\mathrm{pI})$ and $\mathrm{pH}$ of a solution are two important factors affecting the overall particle charge. A significant number of studies conducted on plant-based natural coagulants have prepared synthetic turbid water via the addition of clay or kaolin particles (Table 3). As the pI of kaolin has been reported to be 2.8 (Ndabigengesere and Subba Narasiah 1996), the kaolin particles were negatively charged at the tested water samples. The polysaccharide fraction specifically mucilaginous extracts from $C$. indica and $H$. esculentus has been recognized as potential natural coagulants based on the relatively high turbidity removals reported. The predominant coagulation mechanism leading to particle destabilizations could be postulated to be adsorption and bridging owing to the anionic nature of both the mucilage.

The $\mathrm{pH}$ optimization studies have been conducted on selected vegetables: $C$. indica (Patale and Pandya 2012), $H$. esculentus (Agarwal et al. 2001, 2003) and legumes (Thakre and Bhole 1985; Bhole 1995; Shilpaa et al. 2012; Šćiban et al. 2005; Prodanović et al. 2011). The manipulation of $\mathrm{pH}$ can significantly enhance the efficiency of coagulation process as $\mathrm{pH}$ alters the electrochemical nature of both the solvent and ionic polymers used (Somasundaran et al. 2005). However, the effects of $\mathrm{pH}$ fluctuations are more prominent in polymers with a high degree of ionic charges. Although non-ionic natural polymer such as guar gum is less sensitive to $\mathrm{pH}$ variations, a much greater coagulant dosage can be expected in contrast to the usage of ionic natural polymers (Biggs 2007). This is evident from the optimized coagulant dosage of guar gum where the anionic mucilage of $C$. indica and $H$. esculentus required at least five times lower dosages despite being used at higher initial turbidities (Table 3). Yet, neutral polymers would be ideal for the treatment of water with higher hardness or salinity levels (Biggs 2007).

The two active coagulation agents identified from vegetables and legumes as natural coagulants explicitly polysaccharides and proteins are made up of long polymeric chains. Based on the similarity to the structure of organic polyelectrolytes, the usage of natural polymers can also be correlated to two main controlling factors resulting in coagulation: the conformation and charge properties of polymers (Yu and Somasundaran 1996). Both the mucilage of $H$. esculentus and Opuntia ficus indica contained galacturonic acid which has been found to be an active coagulation agent (El-Mahdy and El-Sebaiy 1984; Miller et al. 2008). The charge density of galacturonic acid which has a weak carboxylic acid group attached to the polymeric chain is $\mathrm{pH}$ dependent (Bolto and Gregory 2007). The carboxylate group of the anionic mucilage is prone to ionization with increments in $\mathrm{pH}$. As a result, the uncoiling and stretching of the polymeric chain is enhanced due to the amplified intramolecular electrostatic repulsions induced by the ionization of the acidic group ( $\mathrm{Yu}$ and Somasundaran 1996).

The optimized $\mathrm{pH}$ for enhanced coagulation activities using the mucilage of $H$. esculentus lied between the mildly acidic and basic regions (Table 3). Generally, a lower solid removal efficiency has been observed at a neutral pH of 7 (Agarwal et al. 2003). At this $\mathrm{pH}$ value, the relative mucilage viscosity was reported to be at its peak (Woolfe et al. 1977). Hence, it would not be surprising that reduced coagulation activities were observed due to the 
increased difficulty in mucilage dispersion. A random coil configuration is most often adopted when polymers are used in water treatment (Bolto and Gregory 2007). At a higher $\mathrm{pH}$ of 9 , the anionic mucilage of $H$. esculentus would uncoil further to attain a flat, dangling form which is beneficial for coagulation enhancements. This is so as a larger quantity of unoccupied spaces on the polymeric chain is introduced for improved bridging of the colloidal particles. Studies have also concluded that the relative mucilage viscosity can be lowered with increasing concentrations of bivalent ions (Woolfe et al. 1977). Owing to the possible variations in particle compositions between the sewage wastewater and tannery effluent, the optimized $\mathrm{pH}$ was obtained in two different regions.

Apart from polysaccharide, proteins which are amphoteric molecules are also greatly affected by $\mathrm{pH}$. Most of the legumes used as natural coagulants worked best at optimized $\mathrm{pH}$ of 7-8.5 (Table 3). The two predominant amino acids present in the seed legumes were reported to be glutamic acid and aspartic acid (Dhawan et al. 1991; Kovalenko et al. 2006; Audu and Aremu 2011; Padhye and Salunkhe 1979; Leterme et al. 1990; Hussain and Basahy 1998). These acidic amino acid side chains have low pI values of below 3.3 (Properties of Amino Acids 2010), contributing to the overall anionic protein surface charge at the optimized $\mathrm{pH}$ values. As such, charge neutralization via the smaller fractions of basic side chains present in the seed legumes, namely lysine, arginine and histidine with pI values larger than 7.6, is most likely the secondary coagulation mechanism.

Generally, residual turbidities of the treated water increased once the optimum $\mathrm{pH}$ has been exceeded (Thakre and Bhole 1985; Bhole 1995; Shilpaa et al. 2012). As the positivity of the individual surface charges declined, the extent of charge neutralization would be reduced. However, the peels of $L$. purpureus and seed extract of $P$. vulgaris were more superior at increased basicity with $\mathrm{pH}$ values $>9$ (Shilpaa et al. 2012; Śćiban et al. 2005). Polymer-induced coagulation is a complex process which is often affected by the roles of various parameters such as the characteristics of solvents and polymers used as well as their interactions on the process behaviours (Somasundaran et al. 2005). The coiling ratio of a polymer with the changing $\mathrm{pH}$ of the solution could be obtained via fluorescence spectroscopy to gauge the most probable polymeric structure ( $\mathrm{Yu}$ and Somasundaran 1996). This aspect of studies would be useful to verify the postulated coagulation mechanisms at any given $\mathrm{pH}$ regions.

Influence of dosage on turbidity reductions

The dosing of coagulants is critical as the process requires care and proper control to achieve the desired quality of treated water. Often at times, poor coagulant dosage results in unsatisfactory treated water quality, owing to the lack of process optimizations. Hence, it is vital to determine the optimum range of coagulant dosage required to achieve maximum turbidity removals at a minimized treatment cost. Among the four coagulation mechanisms, only charge neutralization and bridging are negatively affected by coagulant dosage due to the stoichiometric relationship exhibited (Table 4).

Three possible dosing cases can be obtained, namely under dosing, optimum dosing and over dosing. Figure 2 depicts the effects of coagulant dosage with regard to the efficiency of particle agglomerations via charge neutralization and bridging. Particle restabilization leading to a decline in turbidity removal efficiency can be expected once the optimum coagulant dosage is exceeded. Additional adsorption of the cationic coagulants on the 'readily neutral' colloidal particles would lead to charge reversals and subsequently result in the repulsion of particles hindering particle agglomerations. Overcrowding of coagulants in a solution would also limit the amount of adsorption sites available for particle bridging as complete surface coverage on the coagulant has occurred (Bolto and Gregory 2007). Thus, the addition of more coagulants would not improve the coagulation process further. In contrast, a much-lower-thanrequired coagulant dosage would lead to incomplete and ineffective coagulation as a majority of the colloidal particles are left in suspension (Fig. 2).

The performance of natural coagulants in turbidity removal over a selected range of coagulant dosage has previously been studied: C. indica (Patale and Parikh 2010), H. esculentus (Al-Samawi and Shokralla 1996; Agarwal et al. 2001, 2003; Anastasakis et al. 2009) and various legumes (Mbogo 2008; Asrafuzzaman et al. 2011; Thakre and Bhole 1985; Pritchard et al. 2009; Shilpaa et al. 2012; Śćiban et al. 2005, 2010; Antov et al. 2010; Prodanović et al. 2011; Marobhe et al. 2007). Even when natural coagulants were used as coagulant aids, dosage optimization is equally important to enhance the overall water treatment efficiencies (Bhole 1995).

The concentration of colloidal particles held in suspension is directly related to the initial turbidity of a given water sample as a high initial turbidity translates to a large amount of suspended particles. As such, the coagulant dosage required for complete destabilization via charge neutralization and bridging would somewhat increase proportionally with the concentration of the particles (Table 4). Gradual increments in the coagulant dosage approaching the optimum range have positive effects on enhancing turbidity removals (Marobhe et al. 2007; Patale and Parikh 2010; Thakre and Bhole 1985). However, a surge in residual turbidity has been observed at coagulant dosages beyond the bench point as represented by the optimum dosage, 


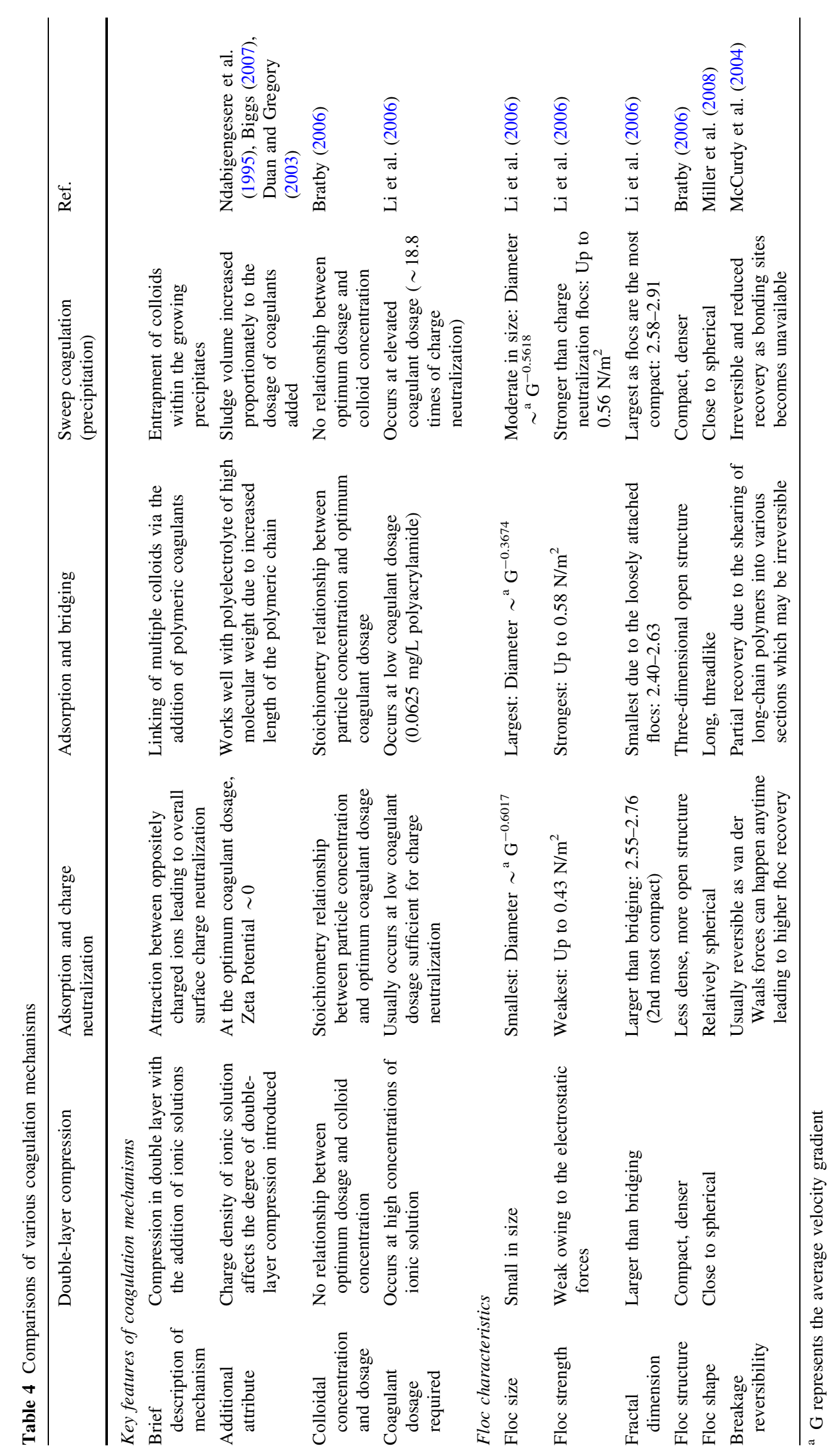


Fig. 2 Effects of coagulant dosage on charge neutralization and bridging

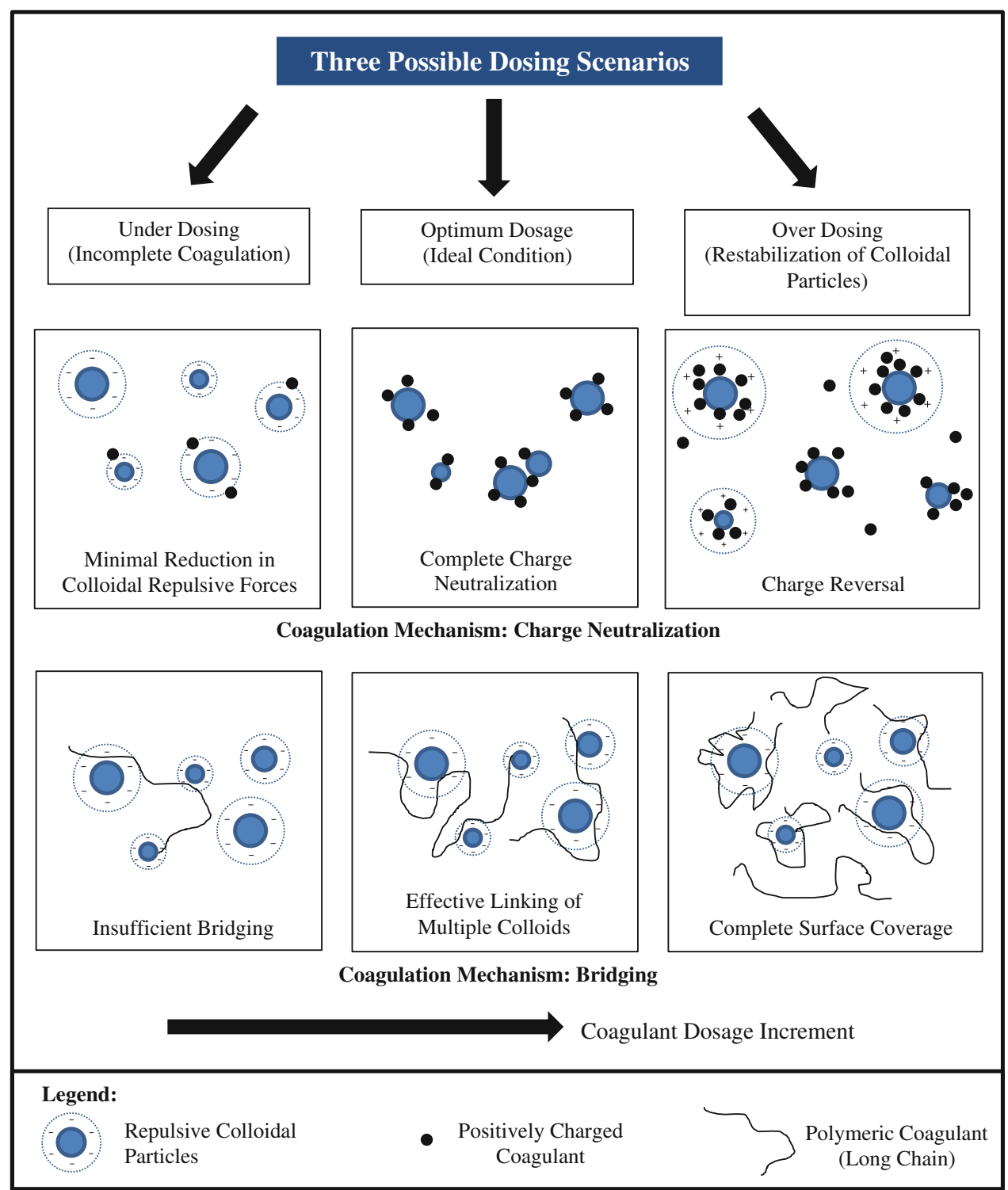

which could be justified by the restabilization of particles due to the overcrowding effect of coagulants (Fig. 2). The optimized natural coagulant dosage corresponded to the highest turbidity removal achieved (Table 3) would serve as a reference when working with such coagulants for water clarifications. Although the surface water characteristics and other process variables may vary, both the polysaccharide and protein fractions as active coagulation agents from vegetables and legumes require precise dosing to attain the desired turbidity removal efficiencies.

\section{Current research gaps and limitations}

The growing importance on minimizing environmental implications has led to changes in both the energy and waste management systems (Nouri et al. 2012), making way for the emergence of cleaner productions while highlighting pollution prevention (Wu et al. 2010). Plantbased natural coagulants could be a worthwhile alternative in addressing the environmental and ecological concerns raised over the usage of chemical coagulants in water clarification. Despite interesting research findings including the recent work carried out on mustard (Bodlund et al. 2013), which suggest to their immense potential as future coagulants, certain aspects of the coagulation studies are still in infantry. The respective coagulation mechanisms for most of the natural coagulants have yet to be understood clearly unlike the widely developed chemical coagulants. Often at times, the active agents responsible for coagulations are made up of different chemical constituents. It is likely that synergistic effects between the polypeptides and polysaccharides in natural coagulants have resulted in the observed coagulation activities. However, this would 
warrant further purification and isolation of the respective active proteins or polysaccharides in grasping the underlying coagulation principles at work. Difficulties in postulating the coagulation mechanism were further heightened with the lack of information, especially in terms of zeta potential measurements. The availability of such data could provide direct indications to the most probable coagulation mechanisms owing to their distinctive features as discussed in Coagulation/destabilization mechanisms section.

While various studies have highlighted the superiority of natural coagulants in inducing particle agglomerations (Table 3), the resultant flocs formed have yet to be analysed and characterized based on floc size, shape and extent of compactness. Such information on floc characteristics could reveal important evidence to support the postulated coagulation mechanisms. It is also vital to determine the floc strength in order to gauge the durability of the floc in resisting breakage. The flocs formed would be subjected to shearing forces in the subsequent water treatment processes if natural coagulants are to be used commercially. Little attention has also been given to the optimization of $\mathrm{pH}$ as one of the major parameters affecting the overall efficiencies in turbidity reduction. Natural coagulants would perform differently when tested over a wide range of $\mathrm{pH}$, and this governs the need to select the ideal $\mathrm{pH}$ at which maximum turbidity reduction can be attained. As $\mathrm{pH}$ plays a vital role in determining the solubility and dominant surface charges of the active coagulation agents, a balance between the extent of $\mathrm{pH}$ adjustments needed and the subsequent turbidity removal efficiencies should be obtained.

\section{Conclusion}

Some of the plant-based natural coagulants presented in this review paper have shown remarkable results and could be adopted either as primary coagulants or coagulant aids. Particle destabilizations resulting from the use of vegetables and legumes were induced via charge neutralization and bridging. Although numerous studies have utilized such extracts for turbidity removals, commercialization and industrial applications are still lacking. They have the potential to be explored further as alternatives in clarifying turbid water. In-depth studies on the characterizations of the active coagulant compounds would be beneficial to gain the necessary knowledge in understanding their respective coagulation activities. The efficiency of natural coagulants could be heightened with the optimization on both the $\mathrm{pH}$ and coagulant dosage used. Gradual introduction to the existing water treatment technology is possible once the bottlenecks of commercialization and limitations of natural coagulants have been resolved.

Acknowledgments The authors are grateful to Monash University Sunway Campus Malaysia for providing the research support needed for this work. Choy Sook Yan is a recipient of the Higher Degree by Research Scholarship (HDR) awarded by Monash University Sunway Campus Malaysia.

\section{References}

Abidin ZZ, Ismail N, Yunus R, Ahamad I, Idris A (2011) A preliminary study on Jatropha curcas as coagulant in wastewater treatment. Environ Technol 32(9):971-977

Agarwal M, Srinivasan R, Mishra A (2001) Study on flocculation efficiency of okra gum in sewage waste water. Macromol Mater Eng 286(9):560-563

Agarwal M, Rajani S, Mishra A, Rai JSP (2003) Utilization of okra gum for treatment of tannery effluent. Int $\mathrm{J}$ Polym Mater 52(11-12):1049-1057

Ahmad F, Gaur PM, Croser J (2005) Chickpea (Cicer arietinum L.). In: Singh RJ, Jauhar PP (eds) Genetic resources, chromosome engineering and crop improvement: grain legumes, vol 1. CRC Press, Boca Raton, FL, pp 187-217

Al-Samawi AA, Shokralla EM (1996) An investigation into an indigenous natural coagulant. J Environ Sci Health A Toxic Hazard Subst Environ Eng 31(8):1881-1897

Amarowicz R, Dykes GA, Pegg RB (2008) Antibacterial activity of tannin constituents from Phaseolus vulgaris, Fagoypyrum esculentum, Corylus avellana and Juglans nigra. Fitoterapia 79:217-219

Anastasakis K, Kalderis D, Diamadopoulos E (2009) Flocculation behavior of mallow and okra mucilage in treating wastewater. Desalination 249:786-791

Antov MG, Šćiban MB, Petrović NJ (2010) Proteins from common bean (Phaseolus vulgaris) seed as a natural coagulant for potential application in water turbidity removal. Bioresour Technol 101:2167-2172

Asrafuzzaman M, Fakhruddin ANM, Alamgir Hossain M (2011) Reduction of turbidity of water using locally available natural coagulants. ISRN Microbiol 2011:1-6

Atasie VN, Akinhanmi TF, Ojiodu CC (2009) Proximate analysis and physico-chemical properties of groundnut (Arachis hypogaea L.). Pak J Nutr 8(2):194-197

Audu SS, Aremu MO (2011) Effect of processing on chemical composition of red kidney bean (Phaseolus vulgaris L.) flour. Pak J Nutr 10(11):1069-1075

Bhole AG (1995) Relative evaluation of a few natural coagulants. J Water Supply Res Technol 44(6):284-290

Biggs S (2007) Polymeric flocculants. Encyclopedia of surface and colloid science, 2nd edn. Taylor \& Francis, New York, pp 4973-4989

Bodlund I, Pavankumar AR, Chelliah R, Kasi S, Sankaran K, Rajarao GK (2013) Coagulant proteins identified in Mustard: a potential water treatment agent. Int $\mathbf{J}$ Environ Sci Technol 1-8. doi:10. 1007/s13762-013-0282-4

Bolto B, Gregory J (2007) Organic polyelectrolytes in water treatment. Water Res 41:2301-2324

Boshou L, Corley H (2006) Groundnut. In: Singh RJ (ed) Genetic resources, chromosome engineering and crop improvement: oilseed crops. Genetic resources chromosome engineering \& crop improvement, vol 4. CRC Press, Boca Raton, FL, pp 51-77 
Bratby J (2006) Coagulation and flocculation in water and wastewater treatment, 2nd edn. IWA Publishing, UK

Brink M (2006) Macrotyloma uniflorum (Lam.) Verde. In: Brink M, Belay G (eds) Plant resources of tropical Africa 1. Cereals and pulses. PROTA Foundation/Backhuys Publishers/CTA, Wageningen

Çalişir S, Özcan M, Haciseferoğullari H, Yildiz MU (2005) A study on some physico-chemical properties of Turkey okra (Hibiscus esculenta L.) seeds. J Food Eng 68:73-78

Chang N, Islam M, Wanielista M (2012) Floating wetland mesocosm assessment of nutrient removal to reduce ecotoxicity in stormwater ponds. Int J Environ Sci Technol 9(3):453-462

Chen Y, Zhang XX, Wu B, Liu B, Xiao L, Li A, Cheng S (2012) Semivolatile organic compounds removal and health risk reduction in drinking water treatment biofilters applying different backwashing strategies. Int $\mathrm{J}$ Environ Sci Technol 9(4):661-670

Chu WH, Gao NY, Yin DQ, Deng Y, Templeton MR (2012) A predictive model for the formation potential of dichloroacetamide, a nitrogenous disinfection by-product formed during chlorination. Int J Environ Sci Technol 9(4):701-704

Compaoré WR, Nikièma PA, Bassolé HIN, Savadogo A, Mouecoucou J, Hounhouigan DJ, Traoré SA (2011) Chemical composition and antioxidative properties of seeds of Moringa oleifera and pulps of Parkia biglobosa and Adansonia digitata commonly used in food fortification in Burkina Faso. Curr Res J Biol Sci 3(1):64-72

Crittenden JC, Trussell RR, Hand DW, Howe KJ, Tchobanoglous G (2005) Water treatment-principles and design, 2nd edn. Wiley, Hoboken, New Jersey

Dairo FAS (2008) Assessment of loofah gourd seeds Luffa cylindrica (ROEM) on performance and some haematological indices of rabbit weaners In: Proceedings of the 9th World Rabbit Congress, Verona, Italy, 10-13 June 2008. World Rabbit Science Association, pp 613-618

De Carvalho CCCR, Cruz PA, Da Fonseca MMR, Xavier-Filho L (2011) Antibacterial properties of the extract of Abelmoschus esculentus. Biotechnol Bioprocess Eng 16:971-977

Dhawan K, Malhotra S, Dahiya BS, Singh D (1991) Seed protein fractions and amino acid composition in gram (Cicer arietinum). Plant Foods Hum Nutr 41:225-232

Dorea CC (2006) Use of Moringa spp. seeds for coagulation: a review of a sustainable option. Water Sci Technol Water Supply 6(1):219-227

Duan J, Gregory J (2003) Coagulation by hydrolysing metal salts. Adv Colloid Interface Sci 100-102:475-502

Duan J, Niu A, Shi D, Wilson F, Graham NJD (2009) Factors affecting the coagulation of seawater by ferric chloride. Desalin Water Treat 11:173-183

El-Mahdy AR, El-Sebaiy LA (1984) Preliminary studies on the mucilages extracted from okra fruits, taro tubers, Jew's mellow leaves and fenugreek seeds. Food Chem 14(4):237-249

Fageria NK, Baligar VC, Jones CA (2010) Growth and mineral nutrition of field crops, 3rd edn. CRC Press, Boca Raton, FL

Frederic Rosengarten J (2004) The book of edible nuts. Dover Publications, USA

Ghadge PN, Vairagar PR, Prasad K (2008) Some physical properties of chick pea split (Cicer arietinum L.). Agric Eng Int CIGR EJ 10:1-9

Ghebremichael K (2007) Overcoming the drawbacks of natural coagulants for drinking water treatment. Water Sci Technol Water Supply 7(4):87-93

Gholikandi GB, Noorisepehr M, Dehghanifard E, Koolivand A, Dehnavi A, Moalej S (2012) Application of modified qualitative index for surveillance of water-filtration process in turbidity removal by different media. Int $\mathrm{J}$ Environ Sci Technol 9(4):691-700

Gunaratna KR, Garcia B, Andersson S, Dalhammar G (2007) Screening and evaluation of natural coagulants for water treatment. Water Sci Technol Water Supply 7(5-6):19-25

Gupta VK, Mittal A, Malviya A, Mittal J (2009) Adsorption of carmoisine A from wastewater using waste materials-bottom ash and deoiled soya. J Colloid Interface Sci 335:24-33

Gupta V, Agarwal S, Saleh TA (2011a) Chromium removal by combining the magnetic properties of iron oxide with adsorption properties of carbon nanotubes. Water Res 45:2207-2212

Gupta VK, Agarwal S, Saleh TA (2011b) Synthesis and characterization of alumina-coated carbon nanotubes and their application for lead removal. J Hazard Mater 185:17-23

Hori Y, Sato S, Hatai A (2006) Antibacterial activity of plant extracts from azuki beans (Vigna angularis) in vitro. Phytother Res 20:162-164

Hussain MA, Basahy AY (1998) Nutrient composition and amino acid pattern of cowpea (Vigna unguiculata (L.) Walp, Fabaceae) grown in the Gizan area of Saudi Arabia. Int J Food Sci Nutr 49:117-124

Jansen PCM (2006a) Vigna angularis (Willd.) Ohwi \& H. Ohashi. In: Brink M, Belay G (eds) Plant resources of tropical Africa 1. Cereals and pulses. PROTA Foundation/Backhuys Publishers/ CTA, Wageningen

Jansen PCM (2006b) Vigna mungo (L.) Hepper. In: Brink M, Belay G (eds) Plant resources of tropical Africa 1. Cereals and pulses. PROTA Foundation/Backhuys Publishers/CTA, Wageningen

Jiang JQ (2001) Development of coagulation theory and prepolymerized coagulants for water treatment. Separ Purif Rev 30(1):127-141

Kim S-H, Moon B-H, Lee H-I (2001) Effects of pH and dosage on pollutant removal and floc structure during coagulation. Microchem J 68:197-203

Kovalenko IV, Rippke GR, Hurburgh CR (2006) Determination of amino acid composition of soybeans (Glycine max) by nearinfrared spectroscopy. J Agric Food Chem 54:3485-3491

Lawrence R (2003) Plant and algal gums and mucilages. In: Tomasik $\mathrm{P}$ (ed) Chemical and functional properties of food saccharides. CRC Press, Boca Raton, FL, p 440

Leterme P, Monmart T, Baudart E (1990) Amino acid composition of pea (Pisum sativum) proteins and protein profile of pea flour. J Sci Food Agric 53:107-110

Li T, Zhu Z, Wang D, Yao C, Tang H (2006) Characterization of floc size, strength and structure under various coagulation mechanisms. Powder Technol 168:104-110

Lim TK (2012) Edible medicinal and non-medicinal plants, vol 2, Fruits. Springer, New York

Lu X, Huang M (2012) Correlation between water quality and the diurnal variation of Pontederia cordata's physiology. Int J Environ Sci Technol 9(2):311-318

Luo J, Farrell J (2013) Understanding pH effects on trichloroethylene and perchloroethylene adsorption to iron in permeable reactive barriers for groundwater remediation. Int J Environ Sci Technol 10(1):77-84

Marobhe NJ, Dalhammar G, Gunaratna KR (2007) Simple and rapid methods for purification and characterization of active coagulants from the seeds of Vigna unguiculata and Parkinsonia aculeata. Environ Technol 28(6):671-681

Mataka LM, Henry EMT, Masamba WRL, Sajidu SM (2006) Lead remediation of contaminated water using Moringa Stenopetala and Moringa oleifera seed powder. Int J Environ Sci Technol 3(2):131-139

Mavura WJ, Chemelil MC, Saenyi WW, Mavura HK (2008) Investigation of chemical and biochemical properties of Maerua 
subcordata plant extract: a local water clarification agent. Bull Chem Soc Ethiop 22(1):143-148

Mbogo SA (2008) A novel technology to improve drinking water quality using natural treatment methods in rural Tanzania. J Environ Health 70(7):46-50

McCurdy K, Carlson K, Gregory D (2004) Floc morphology and cyclic shearing recovery: comparison of alum and polyaluminum chloride coagulants. Water Res 38:486-494

Melnick RL, Huff J, Haseman JK, Dieter MP, Grieshaber CK (1983) Chronic effects of agar, guar gum, gum arabic, locust-bean gum, or tara gum in F344 rats and B6C3F1 mice. Food Chem Toxicol 21(3):305-311

Miller SM, Fugate EJ, Craver VO, Smith JA, Zimmerman JB (2008) Toward understanding the efficacy and mechanism of Opuntia spp. as a natural coagulant for potential application in water treatment. Environ Sci Technol 42(12):4274-4279

Mirhosseini H, Amid BT (2012) A review study on chemical composition and molecular structure of newly plant gum exudates and seed gums. Food Res Int 46:387-398

Mittal A, Gupta V, Malviya A, Mittal J (2008) Process development for the batch and bulk removal and recovery of a hazardous, water-soluble azo dye (Metanil Yellow) by adsorption over waste materials (Bottom Ash and De-Oiled Soya). J Hazard Mater 151:821-832

Mittal A, Kaur D, Malviya A, Mittal J, Gupta V (2009a) Adsorption studies on the removal of coloring agent phenol red from wastewater using waste materials as adsorbents. J Colloid Interface Sci 337:345-354

Mittal A, Mittal J, Malviya A, Gupta V (2009b) Adsorptive removal of hazardous anionic dye "Congo red" from wastewater using waste materials and recovery by desorption. J Colloid Interface Sci 340:16-26

Mittal A, Mittal J, Malviya A, Gupta V (2010a) Removal and recovery of Chrysoidine $\mathrm{Y}$ from aqueous solutions by waste materials. J Colloid Interface Sci 344:497-507

Mittal A, Mittal J, Malviya A, Kaur D, Gupta V (2010b) Adsorption of hazardous dye crystal violet from wastewater by waste materials. J Colloid Interface Sci 343(2):463-473

Mittal A, Mittal J, Malviya A, Kaur D, Gupta V (2010c) Decoloration treatment of a hazardous triarylmethane dye, Light Green SF (Yellowish) by waste material adsorbents. J Colloid Interface Sci 342:518-527

Muyibi SA, Evison LM (1996) Coagulation of turbid water and softening of hardwater with Moringa oleifera seeds. Int J Environ Stud 49(3):247-259

Nagar R, Sarkar D, Makris K, Datta R (2013) Inorganic arsenic sorption by drinking-water treatment residual-amended sandy soil: effect of soil solution chemistry. Int J Environ Sci Technol 10(1):1-10

Ndabigengesere A, Subba Narasiah K (1996) Influence of operating parameters on turbidity removal by coagulation with Moringa oleifera seeds. Environ Technol 17:1103-1112

Ndabigengesere A, Subba Narasiah K (1998a) Quality of water treated by coagulation using Moringa oleifera seeds. Water Res 32(3):781-791

Ndabigengesere A, Subba Narasiah K (1998b) Use of Moringa oleifera seeds as a primary coagulant in wastewater treatment. Environ Technol 19(8):789-800

Ndabigengesere A, Subba Narasiah K, Talbot BG (1995) Active agents and mechanism of coagulation of turbid waters using Moringa oleifera. Water Res 29(2):703-710

Nouri J, Nouri N, Moeeni M (2012) Development of industrial waste disposal scenarios using life-cycle assessment approach. Int J Environ Sci Technol 9(3):417-424

Odiyo J, Chimuka L, Mamali M, Fatoki O (2012) Trophic status of Vondo and Albasini Dams; impacts on aquatic ecosystems and drinking water. Int J Environ Sci Technol 9(2):203-218
Okuda T, Baes AU, Nishijima W, Okada M (2001) Coagulation mechanism of salt solution-extracted active component in Moringa oleifera seeds. Water Res 35(3):830-834

Olajide JO, Igbeka JC (2003) Some physical properties of groundnut kernels. J Food Eng 58:201-204

Osman MA (2007) Effect of different processing methods, on nutrient composition, antinutrional factors, and in vitro protein digestibility of Dolichos lablab bean [Lablab purpuresus (L.) sweet]. Pak J Nutr 6(4):299-303

Oyetayo FL, Oyetayo VO, Ajewole V (2007) Phytochemical profile and antibacterial properties of the seed and leaf of the Luffa plant (Luffa cylindrica). J Pharmacol Toxicol 2(6):586-589

Padhye VW, Salunkhe DK (1979) Biochemical studies on black gram (Phaseolus mungo L.) seeds: amino acid composition and subunit constitution of fractions of the proteins. J Food Sci 44(2):606-610

Patale V, Pandya J (2012) Mucilage extract of Coccinia indica fruit as coagulant-flocculent for turbid water treatment. Asian J Plant Sci Res 2(4):442-445

Patale V, Parikh P (2010) A preliminary study on Coccinia indica fruit mucilage extract as coagulant-flocculent for turbid water treatment. J Pure Appl Sci 18:27-30

Percival SL, Walker JT, Hunter PR (2000) Water supply, treatment and distribution. Microbiological aspects of biofilms and drinking water. Microbiology of extreme \& unusual environments. CRC Press, Boca Raton, FL, pp 1-14

Peter Rory E, Qi W, Phillippa R, Yilong R, Simon R-M (2001) Guar gum: agricultural and botanical aspects, physicochemical and nutritional properties, and its use in the development of functional foods. In: Cho SS, Dreher ML (eds) Handbook of dietary fiber. Marcel Dekker, Inc., New York

Pritchard M, Mkandawire T, Edmondson A, O'neill JG, Kululanga G (2009) Potential of using plant extracts for purification of shallow well water in Malawi. Phys Chem Earth 34:799-805

Prodanović JM, Šćiban MB, Antov MG, DodiĆ JM (2011) Comparing the use of common bean extracted natural coagulants with centrifugation in the treatment of distillery wastewaters. Rom Biotechnol Lett 16(5):6638-6647

Properties of Amino Acids (2010) Amino acids, peptides, and proteins. In: Lundblad RL, Macdonald FM (eds) Handbook of biochemistry and molecular biology, 4th edn. CRC Press, Boca Raton, FL, pp 3-6

Raghuwanshi PK, Mandloi M, Sharma AJ, Malviya HS, Chaudhari S (2002) Improving filtrate quality using agrobased materials as coagulant aid. Water Qual Res J Can 37(4):745-756

Ravindran R, Bino Sundar ST (2009) Nutritive value of horse gram (Dolichos biflorus) for egg-type chicks and growers. Tamilnadu J Vet Anim Sci 5(4):125-131

Saeed S, Tariq P (2005) Antibacterial activities of Mentha piperita, Pisum sativum and Momordica charantia. Pak J Bot 37(4):997-1001

Sahoo PK, Srivastava AP (2002) Physical properties of okra seed. Biosyst Eng 83(4):441-448

Šćiban MB, Klašnja MT, Stojimirović JL (2005) Investigation of coagulation activity of natural coagulants from seeds of different leguminose species. Acta Period Technol 36:81-87

Šćiban MB, Vasić MA, Prodanović JM, Antov MG, Klašnja MT (2010) The investigation of coagulation activity of natural coagulants extracted from different strains of common bean. Acta Period Technol 41:141-147

Shaheed A, Templeton MR, Matthews RL, Tripathi SK, Bhattarai K (2009) Disinfection of waterborne coliform bacteria using Luffa cylindrica fruit and seed extracts. Environ Technol 30(13):1435-1440

Shaheen SZ, Bolla K, Vasu K, Singara Charya MA (2009) Antimicrobial activity of the fruit extracts of Coccinia indica. Afr J Biotechnol 8(24):7073-7076 
Shilpaa BS, Akankshaa K, Girish P (2012) Evaluation of cactus and hyacinth bean peels as natural coagulants. Int $\mathbf{J}$ Chem Environ Eng 3(3):187-191

Sincero GA, Sincero AP (2002) Coagulation. In: Physical-chemical treatment of water and wastewater. CRC Press, Boca Raton, FL

Small E (2009) Top 100 food plants. NRC Research Press, Ottawa

Small E (2011) Top 100 exotic food plants. CRC Press, Boca Raton, FL

Snoeyink VL, Scott Summers R (1999) Adsorption of organic compounds. In: Letterman RD (ed) Water quality and treatment: a handbook of community water supplies, 5th edn. McGrawHill, New York, pp 13.11-13.83

Somasundaran P, Runkana V, Kapur PC (2005) Flocculation and dispersion of colloidal suspensions by polymers and surfactants: experimental and modeling studies. In: Stechemesser H, Dobiás B (eds) Coagulation and flocculation, 2nd edn. CRC Press, Boca Raton, FL, pp 767-803

Sowmeyan R, Santhosh J, Latha R (2011) Effectiveness of herbs in community water treatment. Int Res $\mathrm{J}$ Biochem Bioinform 1(11):297-303

Subramanium S, Nand V, Maata M, Koshy K (2011) Moringa oleifera and other local seeds in water purification in developing countries. Res J Chem Environ 15(2):135-138

Tavakoli H, Rajabipour A, Mohtasebi SS (2009) Moisture-dependent some engineering properties of soybean grains. Agric Eng Int CIGR EJ XI: Manuscript 1110

Thakre VB, Bhole AG (1985) Relative evaluation of a few natural coagulants. J Inst Eng (India) Environ Eng Div 65:89-92

Tripathi PN, Chaudhuri M, Bokil SD (1976) Nirmali seed-a naturally occurring coagulant. Indian $\mathrm{J}$ Environ Health 18(4):272-281

UNICEF/WHO (2009) Diarrhoea: why children are still dying and what can be done, WHO, Geneva
Unnisa SA, Deepthi P, Mukkanti K (2010) Efficiency studies with Dolichos lablab and solar disinfection for treating turbid waters. J Environ Protect Sci 4:8-12

Vijayaraghavan G, Sivakumar T, Vimal Kumar A (2011) Application of plant based coagulants for waste water treatment. Int J Adv Eng Res Stud 1(1):88-92

Wang X, Wang J (2012) Denitrification of nitrate-contaminated groundwater using biodegradable snack ware as carbon source under low-temperature condition. Int J Environ Sci Technol 9(1):113-118

Woolfe ML, Chaplin MF, Otchere G (1977) Studies on the mucilages extracted from okra fruits (Hibiscus esculentus L.) and baobab leaves (Adansonia digitata L.). J Sci Food Agric 28:519-529

Wortmann CS (2006) Phaseolus vulgaris L. (common bean). In: Brink M, Belay G (eds) Plant resources of tropical Africa 1. Cereals and pulses. PROTA Foundation/Backhuys Publishers/ CTA, Wageningen

Wu TY, Mohammad AW, Jahim JM, Anuar N (2010) Pollution control technologies for the treatment of palm oil mill effluent (POME) through end-of-pipe processes. J Environ Manag 91(7):1467-1490

Yalçin I (2007) Physical properties of cowpea (Vigna sinensis L.) seed. J Food Eng 79:57-62

Yalçin I, Özarslan C, Akbaş T (2007) Physical properties of pea (Pisum sativum) seed. J Food Eng 79:731-735

Yin C-Y (2010) Emerging usage of plant-based coagulants for water and wastewater treatment. Process Biochem 45:1437-1444

Yongabi KA (2010) Biocoagulants for water and waste water purification: a review. Int Rev Chem Eng 2(3):444-458

Yu X, Somasundaran P (1996) Role of polymer conformation in interparticle-bridging dominated flocculation. J Colloid Interface Sci 177:283-287 